University of Tennessee Law

Legal Scholarship Repository: A Service of the Joel A. Katz Library

UTK Law Faculty Publications

$12-2016$

A More Charitable Charity: Administrative Necessity Provides an Opportunity to Promote Altruism in Charities

Eric Franklin Amarante

Follow this and additional works at: https://ir.law.utk.edu/utklaw_facpubs

Part of the Law Commons 


\title{
A MORE CHARITABLE CHARITY: ADMINISTRATIVE NECESSITY PROVIDES AN OPPORTUNITY TO PROMOTE ALTRUISM IN CHARITIES
}

\author{
Eric Franklin*
}

\begin{abstract}
The law of charities governs an absurdly wide-ranging field of organizations. A small group of antiquated statutes purport to govern a diversity of entities that range from hospitals worth millions of dollars to purely volunteer-run organizations that provide free childcare. Given the expansive nature of the law of charities, perhaps it is understandable that the law lacks a coherent guiding principle. This alone would not be problematic if not for the fact that most tax-exempt organizations do not comport with the general public's idea of charity. An intuitive definition of charity relies upon a lack of self-regard. In other words, charity requires some level of altruism. But many charities pay lavish salaries and some are major players in the crass commercialism of the private market; such activities are far from any reasonable definition of altruism. Thus, to the extent that we expect charitable organizations to exhibit some level of altruism, the concept of charity has been stretched to a level that is almost unrecognizable.

In addition to diluting the concept of charity, the over-inclusive nature of tax-exempt law resulted in an unreasonable administrative burden for the IRS. Entities vying for charitable status flooded the agency with tax-exempt applications, crippling the IRS and resulting in an unacceptable backlog. To address this, the IRS created a streamlined application to make the application process more efficient. But critics claim that the streamlined process lacks anything resembling rigor and provides precious little data for evaluation.

Somewhat surprisingly, and certainly unintentionally, the IRS's solution to its administrative burden provides an opportunity to address the law allowing charities to act in a less-than-altruistic manner. The IRS's desperate attempt to curtail its administrative burden presents the occasion to create a new family of charities - one that does not strain any traditional definition of "charity." This Article argues that, in exchange for the use of
\end{abstract}

\footnotetext{
* Associate Professor of Law and Director of the Small Business and Nonprofit Legal Clinic, William S. Boyd School of Law, University of Nevada, Las Vegas; B.A. University of Texas at Austin (1993); J.D. Cornell Law School (2005). The author would like to thank Andrew Martineau for his invaluable research assistance.
} 
this streamlined process, charities should agree to forgo salaried employees and commercial activity. Such charities will, in a very real sense, be forced to operate in a more altruistic manner. Thus, these charities will be, in a sense, more charitable.

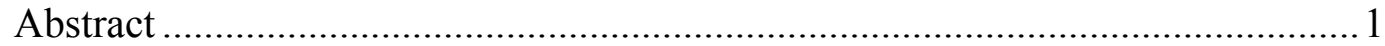

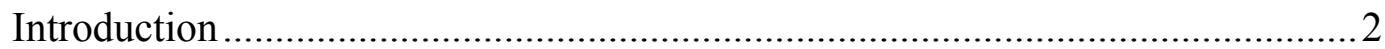

I. Defining Charity: Practicality Trumps Idealism............................................... 7

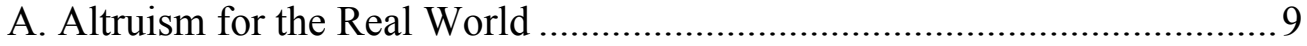

1. Nondistribution Constraint .............................................................. 11

2. Prohibition of Private Inurement .................................................. 13

3. Restriction to Charitable Activities ................................................ 15

B. Compromised Altruism Undermined ....................................................... 16

1. Reasonable Salaries ......................................................................... 16

2. Commercial Activity .................................................................. 18

3. An Eroding Altruism ................................................................... 21

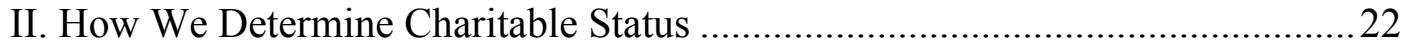

A. The Form 1023 vs. The Form 1023-EZ ....................................................24

1. The Form 1023 ..........................................................................24

2. The Form 1023-EZ: "A radical change to a decades-old process" .................................................................................... 26

B. Why The Streamlined Process Fails......................................................29

1. The Form 1023-EZ Fails the Educational Role ..............................29

2. The Form 1023-EZ Does Not Provide the IRS With Enough Information to Adequately Assess Applicants .................................. 31

III. An Opportunity to Make Charities More Altruistic ....................................... 34

A. Should We Treat Form 1023-EZ Filers Differently?............................... 35

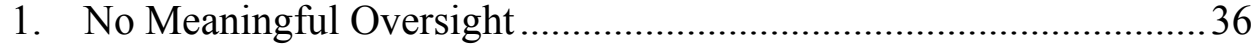

2. Insufficiency of Disclosure for Small Charities ...............................39

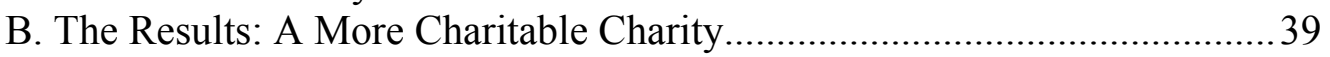

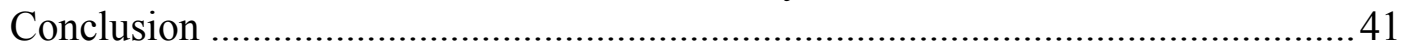

\section{INTRODUCTION}

No one is quite sure why charities are exempt from taxes. ${ }^{1}$ And make no mistake: the exemption is significant. ${ }^{2}$ In 2013 alone, nonprofit organizations reported $\$ 2.26$ trillion in revenues and $\$ 5.17$ trillion in

\footnotetext{
1 "It is extraordinary that no generally accepted rationale exists for the multi-billion dollar exemption from income and property taxes that is universally conferred on 'charitable' institutions" - Colombo 91, 1381

${ }^{2}$ Crimm 424 ("The magnitude of the pecuniary benefit enjoyed by charitable organizations because of various tax exemptions is enormous")
} 
assets. ${ }^{3}$ By one estimate, this amounts to approximately five percent of America's gross domestic product. ${ }^{4}$ If accurate, this is a staggering amount of potential tax revenue. Given the size of the sector, one would assume that there is a well-reasoned justification for foregoing this revenue. Unfortunately, that assumption is incorrect.

Despite the fact that America's definition of charity can trace its roots to the dawn of the $17^{\text {th }}$ century in England, ${ }^{5}$ legal scholars have only recently attempted to justify the tax-exempt nature of certain charities. Most theories are predominately descriptive in nature, with some normative elements. ${ }^{6}$ But they each fail to provide a comprehensively descriptive account of the tax-exemption of charities. ${ }^{7}$ The traditional theory posits that we should promote charitable activity through tax-exemption because charities lighten the burden of the government. ${ }^{8}$ Other leading theories ${ }^{9}$ suggest economic

3 This number represents reporting nonprofits, and only accounts for $35 \%$ of the nonprofit organizations registered with the IRS. Urban Institute, National Center for Charitable Statistics. http://www.urban.org/research/publication/nonprofit-sector-brief2015-public-charities-giving-and-volunteering.

4 Tax-Exempt Organizations: Better Compliance Indicators and Data, and More Collaboration with State Regulators Would Strengthen Oversight of Charitable Organizations, United States Government Accountability Office, December 2014, Page 1 (GAO Report).

${ }^{5}$ Linda Sugin, Rhetoric and Reality in the Tax Law of Charity, 84 FORDHAM L. REV. 101, 101 (2016) ("The definition of charity in American law originates from England's Statute of Charitable Uses. Passed in 1601, the statute coincidentally produced a legal definition of charity."). But see Nina J. Crimm, An Explanation of the Federal Income Tax Exemption for Charitable Organizations: A Theory of Risk Compensation, 50 FLORIDA LAW. R. 419, 425 (1998) ("The seeds of the tax exemption notion for American 'charitable' organizations can be traced to fourteenth century England.").

${ }^{6}$ See Rob Atkinson, Theories of the Federal Income Tax Exemption for Charities: Thesis, Antithesis, and Synthesis, 27 STETSON L. REV. 395, 398 (1991) ("Exemption theories often rest, explicitly or implicitly, on descriptive accounts of the role of charity, but they themselves are normative.").

${ }^{7}$ The reason for this failure is likely due to the very desire to form a coherent theory in the first place. As Professor Atkinson notes, "If ... we want a theory that takes account of the 'charity' of charities..., we are bound to be disappointed. At best, we will find a proxy for what we are inclined to believe is the real criterion. Alternatively, if we admit charity to be a complex phenomenon, we avoid the fallacy of the one true way, but only at the price of a seriously complicated legal definition. ... [W] e can be sure from the outset that a legal definition of charity will not be entirely satisfactory, in large part because some of the things we want in an exemption theory are at odds with others." See Atkinson, supra note [4] at 401-02.

${ }^{8}$ The subsidy theory's roots are found in legislative history. See H.R.Rep. No 751860, at 19 (3d Sess. 1938) ("The exemption from taxation ...is based upon the theory that the Government is compensated for the loss of revenue by its relief from financial burden which would otherwise have to be met by appropriations from public funds.").

${ }^{9}$ Not included in this embarrassingly short and inadequate summary of the theories justifying tax-exemption is Professors Boris Bittker and George Rahdert's foundational 
justifications for the tax-exemption due to market failures, ${ }^{10}$ rationalizations based on the unreasonable amount of risk assumed by nonprofit organizations, ${ }^{11}$ legitimizing the tax-exempt regime based on the sector's promotion of altruism, ${ }^{12}$ and an economic argument that tax-exemption should hinge on the level of donations a charity receives. ${ }^{13}$ However, none of these theories has provided a universally-accepted justification for taxexemption. $^{14}$

This failure is due to the absurdly complex nature of the law governing tax-exempt entities, a complexity born out of a general and persistent carelessness that has characterized the tax-exempt regime since its inception in American law. Our current tax-exempt system was born out of centuries of blindly adopted common law, a hodge-podge of court decisions, and a panoply of unprincipled Congressional acts. This has led to the facially absurd notion that the same vague statute purports to govern the tax exemption of churches, amateur bowling leagues, hospitals, and universities. To put a finer point on it (and highlight the absurdity), a single exemption-Section 501(c)(3) of the Internal Revenue Code (the "Code")-governs the tax-exemption of each of the following organizations: a volunteer-driven charity that provides afterschool mentorship and tutoring to children in a public housing development; ${ }^{15} \mathrm{a}$ hate group that routinely interrupts military funerals with signs reading God Hates Fags and Thank God for Dead Soldiers; ${ }^{16}$ an organization dedicated to preventing domestic violence and sheltering battered women; ${ }^{17}$ an

income measurement theory, which suggests that traditional accounting methods do not permit taxation of nonprofit income. Boris I Bittker \& George K. Rahdert, The Exemption of Nonprofit Organizations from the Federal Income Taxation, 85 YALE L. J. 299 (1976).

${ }^{10}$ See Henry Hansmann, The Rationale for Exempting Nonprofit Organizations from Corporate Income Taxation, 91 YALE L. J. 54 (1981).

${ }^{11}$ See Crimm, supra note [3].

${ }^{12}$ Rob Atkinson, Altruism in Nonprofit Organizations, 31 B.C. L. REV. 501 (1990).

${ }^{13}$ Mark A. Hall \& John D. Colombo, The Donative Theory of the Charitable Tax Exemption, 52 OHIO ST. L.J. 1379 (1991); Mark A. Hall \& John D. Colombo, The Charitable Status of Nonprofit Hospitals: Toward a Donative Theory of Tax Exemption, 66 WASH L. REV. 307 (1991).

14 See Nina Crimm, An Explanation of the Federal Income Tax Exemption for Charitable Organizations: A Theory of Risk Compensation, 50 FLORIDA L. REV. 419 ("[I]t may appear remarkable that there is no universally-accepted theory to explain the fundamental reason underlying the deliberate and continued conferral of [the tax] exemption on all qualifying charitable organizations.").

${ }^{15}$ See Nevada Youth Network, discussed more fully in Section [_ _ ].

${ }^{16}$ See Westboro Baptist Church homepage at http://www.godhatesfags.com/ (warning, site is extremely offensive).

17 See National Coalition Against Domestic Violence homepage at http://www.ncadv.org/about-us/mission 
organization devoted to an obscure sport known as curling, ${ }^{18}$ and a church that promotes suicide, abortion, cannibalism, and sodomy.

Given this poor foundation, it may not be surprising that our charities don't look very, for lack of a better word, charitable. The colloquial definition of "charity," based on the etymological origins of the word, is a "selfless, other-regarding love." 20 It is this lack of self-interest that defines the non-legal conception of charity. But charities in the United States may engage in a number of activities that most would consider antithetical to any definition of "charity" that requires a lack of self-regard. More to the point, charity leaders may earn handsome and lavish salaries and many of our most cherished public charities are major participants in the private market.

Complicating matters, the process for obtaining tax-exempt status is influenced more by administrative necessity than any coherent theoretical foundation. The application process lies in the hands of the Internal Revenue Service (the "IRS"). Regardless of whether the IRS is the proper agency to determine appropriateness of tax-exemption for a particular organization, a query that is beyond the scope of this paper, ${ }^{21}$ the IRS has proven to be wholly incapable of conducting a meaningful investigation into the worthiness of would-be tax-exempt entities in an efficient manner. Setting aside any substantive criticisms of the IRS's tax-exemption application process, ${ }^{22}$ the agency has proven unable to keep up with the number of applicants, amassing an unacceptably large backlog of taxexempt applications. ${ }^{23}$ To address this, the IRS took a rather dramatic step.

With the assumption that not all applications require the same level of scrutiny, the IRS crafted an application process designed specifically for small organizations. Fortunately, the streamlined application process freed up IRS resources to successfully tackle the backlog. But the IRS was able to address the backlog so quickly due to the inadequacy of the streamlined process. It is virtually devoid of either rigor or investigation. For this

18 See USA Curling Association at http://www.teamusa.org/usa-curling/aboutus/about-usa-curling

${ }^{19}$ See Church of Euthanasia at http://www.churchofeuthanasia.org/ (warning, site is extremely offensive).

${ }^{20}$ Atkinson, supra note [4] at 399.

${ }^{21}$ There is a strong argument to be made that the IRS, designed as a tax-collecting entity, was never meant to serve an oversight role.

${ }^{22}$ From a substantive standpoint, many critics claim that unqualified organizations obtain tax-exempt status and that the tax-exempt application process suffered from political targeting. Jackie Calmes, Senate Report Cites I.R.S. Mismanagement in Targeting of Tea Party Groups, N.Y. TIMES, August 5, 2015, ("A Senate committee on Wednesday closed a two-year investigation with unanimous agreement that mismanagement at the Internal Revenue Service led it to improperly target conservative groups seeking tax-exempt status.").

${ }^{23}$ See discussion infra [_ $]$ 
reason, the streamlined application process has been widely criticized, with one commentator noting that "[i]n many communities, it takes more to get a library card than it takes to get this new exempt status." 24 And that criticism is no understatement; it is not an exaggeration to characterize the streamlined process as little more than allowing organizations to opt-in to the tax-exempt realm with virtually no IRS inquiry into the applicants' worthiness.

Although the IRS's decision represents a dramatic change in policy to the tax-exempt application process, it is not the first time that the IRS has decided to lighten the regulatory and administrative burden of smaller nonprofit organizations. Indeed, there is a direct parallel between the streamlined application process for smaller organizations and the required annual information disclosures for smaller organizations. In each case, the IRS has determined that organizations with annual gross receipts of less than $\$ 50,000$ require less scrutiny. From the perspective of applications, we have the recently-enacted streamlined application process for organizations that reasonable expect to less than $\$ 50,000$ in gross receipts in any of the ensuing three years. From the perspective of annual information reports, organizations that had less than $\$ 50,000$ in gross receipts are not required to provide any meaningful disclosures regarding precisely how much money was received by the organization, how any funds were spent, or even if the organization engaged in any meaningful charitable work. Thus, the IRS has determined that any organization that realizes less than $\$ 50,000$ in gross receipts will not be vetted on the front-end (the application stage) or the back-end (during operations).

Unfortunately, although not surprisingly, this policy shift appears to have been made entirely with a view to administrative expediency, without much apparent thoughtful consideration of policy concerns. The IRS looked at the backlog of applications, considered a dwindling budget, ${ }^{25}$ and made a decision based wholly on administrative necessity.

This is a missed opportunity. The streamlined application process provides a chance to reassess the tax-exempt organization regime. The IRS's desperate attempt to curtail its administrative burden presents the occasion to create a new family of charities - one that does not strain any traditional definition of "charity."

This Article argues that, in exchange for the use of this streamlined

\footnotetext{
${ }^{24}$ Patricia Cohen, IR.S. Shortcut to Tax-Exempt Status is Under Fire, The New York Times, April 8, 2015.

${ }_{25}$ "[T] he IRS budget has declined by about $\$ 900$ million since fiscal year 2010 and funding is below fiscal year 2009 levels." GAO Report, supra note [_] at 1; "Staffing has declined by about 10,000 full-time equivalents since fiscal year 2010, and performance has been uneven." GAO Report, supra note [_] at 1.
} 
process and the minimal annual scrutiny, charities should agree to forgo salaried employees and commercial activity. This Article will argue that such restrictions are reasonable responses to the virtual lack of scrutiny endured by such organizations. And by foregoing both salaries and commercial activity, such charities will, in a very real sense, be forced to operate in a more altruistic manner. As such, these charities will be more charitable.

Part I of this Article discusses the charitable legal regime generally. It highlights the law's numerous efforts to impose altruism on charitable organizations, and discusses the various compromises that detract from such efforts. Specifically, this part discusses policies that restrict individuals from obtaining personal enrichment from charitable organizations and the exceptions that undermine such policies. Part II discusses the means by which we award charitable status, paying particular attention to the recently-adopted streamlined application process. This part will pay particular attention to the strongest criticisms of the streamlined application, illustrating how the new process fails to properly vet charities. This part will also discuss the process by which the IRS monitors charitable activity, arguing that the lowered scrutiny enjoyed by small organizations not only at the application process, but also during the organization's operations, provides the justification for imposing a more restrictive spectrum of permissible activities. Part III of this Article explains how the IRS's decisions provide the opportunity to impose more stringent requirements on such entities. Specifically, this section will argue that charities that opt to use the streamlined application ought to be prohibited from paying salaries and engaging in commercial activity. In doing so, not only will the taxexempt regime will create a family of charities that are required to act in a more altruistic manner, but also reduce the risk of such charities operating without oversight.

\section{Defining Charity: Practicality Over IDEALISM}

What comes to mind when you think of a charity? If you are able to set aside legal definitions and real-world examples to reach a more abstract formulation, you will likely focus on the motives of the actor. If the actor is driven by self-interest, greed, or personal gain, then the act is not likely to meet any intuitive definition of charity. This notion that any definition of charity must emphasize a lack of self-regard is in harmony with etymological origins of the word, which recall notions of "selfless, otherregarding love."26 It is this lack of self-interest that defines the non-legal

${ }^{26}$ Atkinson, supra note [4] at 399. 
conception of charity. It expresses "the kind of selfless regard for others that we associate with the core of charity." 27

The conception of charity as a selfless endeavor was perhaps most famously described by attorney and politician Horace Binney. According to Mr. Binney, charity consists of "[w]hatever is given ... free from the stain or taint of every consideration that is personal, private, or selfish." ${ }^{, 28}$ This characterization of charity appeals to our intuitive sense that any definition of charity should only include those acts done without any self-regard. It attempts to codify the popular notion that most people consider charitable acts to be those that are selfless. Or to put it another way, one engages in charity when he or she gives something without an expectation of something in return. The determinative factor is likely to be the level of altruism in the act. ${ }^{29}$ The more altruistic the act, the more comfortable we feel bestowing the "charitable" label to the act.

To the extent this is true, then the popular conception of charity is very different from the legal definition of charity. Charities ${ }^{30}$ in the United States may engage in a number of activities that most would consider neither altruistic nor selfless. More to the point, charity leaders often earn handsome salaries and many of our most cherished public charities are major participants in the private market.

Perhaps we stomach these facially uncharitable actions because of the organizations' concomitant good works. In a vacuum, a leader of a charity who receives an annual salary of over a million dollars does not seem very charitable. But perhaps it is reasonable for the American Cancer Society to pay its chief executive officer over $\$ 1.2$ million in total annual compensation because of the organization's laudable achievements in treating cancer, addressing cancer-related public health issues, and providing services to cancer patients. ${ }^{31}$ Similarly, we may not be comfortable with a charity that oversees a commercial enterprise that makes almost three-quarters of a billion dollars in the private market. But maybe we do not mind that the Girl Scouts of America realize an annual revenue of about $\$ 700$ million from cookie sales in light of their work promoting selfesteem and leadership skills in young girls. ${ }^{32}$

${ }^{27}$ Id. at 421.

${ }^{28}$ See The Girard Will Case, 2 How. 194, 11 U.S. (L.ed.) 205)

${ }^{29}$ Atkinson, supra note [4] at 401 ("The most intuitively appealing single criterion of charitable status is the squishy one we have already identified: selfless love of others.").

${ }^{30}$ For the purposes of this Article, "charity" will refer to a 501(c)(3) organization categorized as a public charity.

${ }^{31}$ See American Cancer Association Form 990 available at [ _ ]

${ }^{32}$ Thornton McEnery and Gus Lubin, How the Girl Scouts Built Their Cookie Empire, BUSINESS INSIDER, March 24, 2011, available at http://www.businessinsider.com/how-thegirl-scouts-built-their-cookie-empire-2011-3. 
The determination of what we consider charity is more than a philosophical concern, as charitable status carries significant consequences. If the IRS bestows 501(c)(3) status to an entity, the entity is not only exempted from federal income taxes, but an entity's donors may also deduct contributions from their personal tax liability. ${ }^{33}$ Further, many states piggyback on the IRS's determination and provide analogous benefits in the form of exemptions from state income and sales taxes. Finally, the 501(c)(3) designation serves as the federal government's explicit imprimatur and strongly suggests that the entity is worthy of special treatment. Given these consequences, it is in our interest to carefully consider the appropriateness of what we allow our charities to do. More specifically, should we allow charities to engage in such patently nonaltruistic acts as paying generous salaries or playing a significant role in the private market?

\section{A. Altruism for the Real World}

If we would prefer our charities to behave in a manner more in line with Mr. Binney's altruistic expectations, we are failing. But perhaps our flexibility is born out of practicality. After all, if we are going to charge a governmental agency with the determination of charitable status, any legal definition of charity must be one that is objectively measurable. And from this perspective, Mr. Binney's definition fails. To require an organization to be "free from the stain or taint of every consideration that is personal, private, or selfish" necessitates some mechanism of reliably gauging individual motives. Gauging the inner motivations of individuals has perplexed philosophers for centuries, and this conundrum is certainly not likely to be solved by the IRS. Thus, if we would like our charities to exhibit altruism, we need an administratively feasible way to measure altruism. However appealing and elegant Mr. Binney's definition of charity may be, it is not an appropriate definition to adopt as government policy because it is virtually impossible to police. How, precisely, is the IRS expected to suss out the motivations of an entity to determine whether or not the entity exhibits any "consideration that is personal, private, or selfish," and is therefore undeserving of tax-exempt status?

Such a test would be, at best, impracticable, and it is for this reason that the Supreme Court of Pennsylvania deemed it infeasible. ${ }^{34}$ Although admitting that Mr. Binney's definition is "undoubtedly charity in its highest and noblest sense," the judge noted that "if we were to apply it to the

33 See generally, Publication 557: Tax-Exempt Status for Your Organization, Department of Treasury, Internal Revenue Service (Rev. February 2016).

${ }^{34}$ Fire Ins. Patrol v. Boyd, 120 Pa. 624 (1888). 
transactions of this wicked world, I fear it would lead to utter embarrassment ... for it is God only who can look into the heart and judge of motives." 35 With the quite reasonable determination that a court is unable to determine the amount of self-interest in any given action, the Supreme Court of Pennsylvania took the position that any legal definition of charity would necessarily be limited to something we can observe. This necessarily rules out the use of individual motives as a measure of charity, because "[i]t would be as vain as it would be unprofitable for a human tribunal to speculate upon the motives of men." 36

Thus, we require a more practical test for determining what constitutes a charity. The IRS has developed a complex regime to determine whether or not an entity deserves the benefits of charitable status, a process that is investigated in depth in Part II of this Article. But several of the core components of the IRS's test are interesting in that they appear to serve as a rough approximation of Mr. Binney's altruistic definition of charities. These components - the nondistribution constraint, the prohibition of private inurement (a close cousin of the nondistribution constraint), and the requirement that charities restrict activities to their charitable purpose-are each discussed in the following sections. However, before discussing how policymakers have attempted to approximate altruism in the laws that govern nonprofits, we should be careful not to impute too much intentionality to the laws and policies that govern tax-exempt entities. The fact that nonprofit law lies on a poorly considered foundation is a frequent lament of nonprofit scholars. ${ }^{37}$ This is, to say the least, troubling. Because charities do not pay any federal income tax, our government has decided to forego a significant potential revenue source. While there are many principled reasons to treat charities differently from other entities, and there are certainly good reasons to promote charitable activity (and perhaps exemption from taxes and other benefits might be the perfect way to promote such activity), this decision was not made in any principled or well-reasoned fashion. It is therefore a bit disingenuous to speak of taxexempt policies designed to approximate altruism. However, I believe the assumptions made in the following sections are both reasonable and defensible.

${ }^{35} \mathrm{Id}$.

${ }^{36}$ Id. The court continued to opine "[w] ho can say that the millionaire who founds a hospital or endows a college, and carves his name thereon in imperishable marble, does so from the love to God and love to his fellow, free from the stain of selfishness? Yet is the hospital or the college any the less a public charity because the primary object of the founder or donor may have been to gratify his vanity...? There is ostentation in giving as well as in the other transactions of life."

${ }^{37}$ See discussion, supra, notes [_ $]$. 


\section{Nondistribution Constraint}

The term "nonprofit," when referring to charities, is a bit of a misnomer. There is, in fact, no restriction prohibiting charities from making a profit. ${ }^{38}$ Indeed, if a charity consistently does not realize any profits, it would probably result in a failure. Profits, after all, are how charities pay for their charitable works. Without profits, Goodwill wouldn't be able to pay rent to keep its stores open, the American Lung Association wouldn't be able to conduct research on lung disease, and Habitat for Humanity wouldn't be able to purchase building materials.

Given the practical necessity of generating profits, and assuming we would like to encourage charitable activity through the tax-exemption process, it would not be a very good policy decision to restrict profitmaking activities by charities. Thankfully, the tax-exempt legal regime does not prohibit charities from making a profit. ${ }^{39}$ Rather, charities have restrictions on how they may spend their profits. To wit: charities may not distribute profits to individuals. This restriction, coined the "nondistribution constraint" by Professor Henry Hansmann, is widely considered the defining characteristic of all charities. ${ }^{40}$ Born out of the provision that prohibits private inurement, ${ }^{41}$ the nondistribution constraint requires that "[n]et earnings, if any, must be retained and devoted in their entirety to financing further production of the services that the organization was formed to provide." 42 The nondistribution constraint is such a core concept in the law of charities that, in order for an organization to enjoy tax-exempt treatment, the organization must have the nondistribution constraint in its formation documents. $^{43}$

Like much of the laws governing tax-exempt entities, policymakers have not expressed a clear justification for the nondistribution constraint. However, there is reason to believe it serves as a practical means of

${ }^{38}$ Henry Hansmann, The Role of Nonprofit Enterprise, 89 YALE L. J. 837, 835 (1980) ("[A] nonprofit organization is not barred from earning a profit. Many nonprofits in fact consistently show an annual accounting surplus.”)

${ }^{39} \mathrm{Id}$.

${ }^{40}$ Id. at 838 .

${ }^{41}$ See discussion infra, notes [ $[$ ]

${ }^{42} \mathrm{Id}$.

${ }^{43}$ Id. ("[T] $[\mathrm{T}$ he nondistribution constraint is imposed, either explicitly or implicitly, as a condition under which the organization receives its corporate charter."). Note that this requirement draws a clear line between nonprofit organizations and for-profit organizations. Corporations are owned by shareholders, limited liability companies are owned by members, and partnerships are owned by partners. Non-profit organizations, on the other hand, have no owners. (("[A] nonprofit corporation is distinguished from a forprofit (or 'business') corporation primarily by the absence of stock or other indicia of ownership that give their owners a simultaneous share in both profits and control."). 
approximating altruism. The nondistribution constraint requires a charity to spend profits in furtherance of its exempt purpose. In other words, charity's profits must be spent in a charitable manner. This is a means of approximating altruism; no matter how much an organization may have in reserves, the organization may not distribute these funds to individuals. ${ }^{44}$ Rather than adopting Mr. Binney's conception of charity, which would require a review of each use of a charity's net earnings to determine the intent motivating such use, the nondistribution constraint attempts to remove any possibility of non-altruistic distributions by requiring all distributions to be charitable in nature. Although this does not completely remove "the stain or taint of every consideration that is personal, private, or selfish," the nondistribution constraint undoubtedly limits the ability of individuals involved with the organization to enrich themselves at the expense of the organization. ${ }^{45}$

Thus, the primary appeal of the nondistribution constraint is that it serves as a practical means to impose altruistic activity. It is a formal restriction against making payments to individuals out of the charity's profits (i.e., a structural impediment to acting with self-regard), and serves as an imposition of an objectively measurable means of ensuring some level of altruism. While we cannot guess as to the motives of individuals running charities, the nondistribution constraint provides some certainty that excess earnings of the organization are not funneled to individuals. And while we are a far cry from a complete absence of "the stain or taint of every consideration that is personal, private, or selfish," the nondistribution constraint serves as a pragmatic mechanism that comes as close to altruism as feasibility allows.

\footnotetext{
${ }^{44}$ This does not include salaries, which are described in more detail below. See infra notes [ $]$.

${ }^{45}$ If the goal of the nondistribution constraint is to increase altruism, the mechanism's success is questionable. Although the IRS requires all charities to include the nondistribution constraint in their formation documents, there is no meaningful policing of the restriction. The responsibility of compliance falls largely upon overworked and uninterested state attorneys general. Hansmann, supra note [_ _ at 873-74. ("[M]ost states ... make little or no effort to enforce [the nondistribution constraint]. As a rule, its enforcement is placed exclusively in the hands of the state's attorney general.... Yet in most states neither the office of the attorney general nor any other office of the state government devotes any appreciable amount of resources to the oversight of nonprofit firms."). But somewhat surprisingly, in the face of impotent policing mechanisms, the nondistribution constraint is widely respected by tax-exempt entities. Professor Hansmann points out that the compliance is self-imposed by the sector, suggesting that "social norms that reinforce legal restraints on profiteering" are enforcing the nondistribution constraint in the presence of "minimal policing." Id at 875. And policing aside, there are, after all, other ways of transferring organizational assets from the charity to an individual. See discussion of salaries, infra notes
} 


\section{Prohibition of Private Inurement}

Despite the nondistribution constraint, there are still many ways to frustrate altruism by transferring value from the nonprofit organization to individuals. Rather than boldly funneling profits to individuals, an organization may provide value by other means. Perhaps an organization provides access to charity-owned vehicles or allows an individual use office space rent-free. Such a transaction would not only frustrate any ideals of altruism, but would also render the nondistribution constraint relatively toothless.

To confront these potential problems, the language that provides the basis for the nondistribution constraint has been interpreted broadly. The Code dictates that tax-exemption is available only for organizations in which "no part of the net earnings ... inures to the benefit of any private shareholder or individual." 46 This "oddly phrased and thoroughly antiquated language" is known as the private inurement doctrine ${ }^{47}$ and is found in one of the earliest iterations of the act exempting certain organizations from taxes. ${ }^{48}$ This provision has far-reaching implications. The definition of "private shareholder or individual" is notably comprehensive, and includes any person who has a "personal and private interest in the activities of the organization." 49 Such a definition includes the obvious candidates for private inurement, such as officers, directors, or members, and also has been read to include any individual who has a "close relationship" with the organization "when he, she, or it is in a position to exercise a significant degree of control over it." ${ }^{30}$ As summarized by the IRS, the private inurement prohibition seeks to proscribe situations in which a "financial benefit represents a transfer of the organization's financial resources to an individual solely by virtue of the individual's relationship with the organization, without regard to accomplishing exempt purposes."

There is good reason to believe that the private inurement restriction has its basis in altruism. This is facially evident, as the language prevents individuals from receiving benefits from an organization. There is,

${ }^{46} 26$ CFR 1.501(c)(3)

${ }^{47}$ Bruce Hopkins, The Law OF TAX-Exempt Organizations, $10^{\text {th }}$ Edition (2011) at 506 ("The contemporary meaning of this statutory language is barely reflected in its literal form.".).

${ }^{48}$ Darryll K. Jones, The Scintilla of Individual Profit: In Search of Private Inurement and Excess Benefit, 19 VIRGINIA TAX REVIEW 4, 575, 590 (2000) (speaking of the private inurement prohibition)

${ }^{49} 26$ CFR 1.501(a)-1(c).

${ }^{50}$ Hopkins, supra note [ $[$ ] at 506.

${ }^{51}$ Gen. Couns. Mem 38459, Cited by Hopkins, supra note [_] at 507. 
however, little in the way of guidance from lawmakers, as "neither Congress, the courts, nor the [IRS] has ever taken the time to explicate the particular categories of private inurement or state their defining principles." ${ }^{, 52}$ Although legislative intent is difficult to ascertain, ${ }^{53}$ Professor Darryll Jones suggests that "the prohibition was intended to exclude any 'element of personal gain,' and to provide exemption to entities 'in which no man receives a scintilla of individual profit." 54 Further, the IRS has stated that the "inurement prohibition serves to prevent anyone in a position to do so from siphoning off any of a charity's income or assets for personal use." 55 This statement, clarifying the doctrine's aim of removing the potential for personal enrichment, is a strong indication that the private inurement restriction's intended goal is to support altruism.

Interestingly, unlike other rules governing activities of charities (e.g., lobbying $^{56}$ or commercial activity), the IRS does not brook any amount of private inurement, no matter how insubstantial. The prohibition is absolute - any amount of private inurement is proscribed. As explained by Professor Hopkins, "none of the income or assets of an exempt organization subject to the private inurement doctrine may be permitted to directly or indirectly unduly benefit an individual."57 Thus, the intent behind the prohibition is clear: the prevention of individuals using tax-exempt charities for personal enrichment. Or to put it another way, "[ $\mathrm{t}]$ he prohibition is designed to prevent the conversion of a tax-exempt endeavor into a personal wealth-creating endeavor. That is, the prohibition prohibits the private taking of the entity's wealth.",58

Similar to the nondistribution constraint, the restriction against private inurement is structured in such a manner that individual motivations are irrelevant. The IRS is not concerned with reasons for the private inurement; rather, all private inurement is barred. The promotion of altruism is clear: the more we can ensure that the assets of the tax-exempt entity are used to engage in charitable works (rather than distributed to individuals), the more

${ }^{52}$ Jones, supra note [ ] ] at 592.

${ }^{53}$ Id. ("The legislative debate on the [prohibition of private inurement] provides perfunctory insight at best.").

${ }^{54} \mathrm{Id}$.

${ }^{55}$ Ge. Couns. Mem. 39861, cited in Hopkins, supra note [ $[$ ] at 507.

${ }^{56} \mathrm{It}$ is well-settled that 501(c)(3) organizations may engage in an insubstantial amount of lobbying, but the reasons for the limitation are not entirely clear. For a more complete discussion, see Elias Clark, The Limitation on Political Activities: A Discordant Note in the Law of Charities, 46 VA. L. REV. 439, 446 (1960) ("It is not clear from the early history of the restriction on political activities whether it evolved as a result of carefully considered policy, or of the Treasury's understandable desire to place outer limits around any exemption, or on the assumption that established property law required it.").

${ }_{58}^{57}$ Hopkins, supra note [_] at 506 (emphasis supplied).

${ }^{58}$ Jones, supra note [_] at 582. 
we have approximated altruism. In conjunction with the nondistribution constraint, the private inurement prohibition works to limit the ability for individuals to realize personal gain from the activities of the charity.

\section{Restriction to Charitable Activities}

Thus far, we've discussed mechanisms designed to ensure some level of altruism in the individuals working with the organization. Together, the nondistribution constraint and the private inurement prohibition work to prevent organizations from funneling money and assets to individuals. But what of the organization itself? Are there mechanisms in place to ensure that the organizations act without self-regard?

As it happens, there are structural provisions in place that limit the activities of charities to ensure they are operated in a certain manner. The Code states that all charities must be "organized and operated exclusively for religious, charitable, scientific, testing for public safety, literary, or educational purposes."

Similar to the prohibition against private inurement, the plain language of this statute suggests a strong prohibition against any activities that do not fall under the one of these categories. After all, the statute states that the organization must not only be organized for such purposes, but also that the organization is "operated exclusively" for such purposes. This therefore appears to be another mechanism to ensure some amount of altruism in our charitable organization. However, the plain language of the statute does not govern, and this statute has been read to permit many activities that would not be considered altruistic.

59 The statute continues to include activities that "foster national or international amateur sports competition (but only if no part of its activities involve the provision of athletic facilities or equipment), or for the prevention of cruelty to children or animals." 26 CFR 1.501(c)(3). This list finds its origins in the English Statute of Charitable Uses, enacted in 1601. See The Statute of Charitable Uses, 43 Eliz., ch 4 (1601), which limited charitable trusts to a lengthy list of enumerated activities, including "Reliefe of the aged impotent and poore people, ... Maintenance of sicke and maymed Souldiers and Marriners, Schooles of Learninge, Free Schooles and Schollers in Universtities, ... Educacion and preferment of Orphans." This list, being both over- and under-inclusive, gave rise to a number of conflicting judicial pronouncements and little in the manner of precedent. Ultimately, nearly two centuries after the enactment of the Statute of Charitable Uses, the famous Pemsel case provided a more useful list of the appropriate activities of charities. As set forth Pemsel, "'Charity' in its legal sense comprises four principal divisions: trusts for the relief of poverty; trusts for the advancement of education; trusts for the advancement of religion; and trusts for other purposes beneficial to the community, not falling under any of the preceding heads." Commissioners of Income Tax v. Pemsel, 1891 App. Cas. 531. 


\section{B. Compromised Altruism Undermined}

As the previous section showed, although the laws governing charities ensure something well short of altruism, the regime boasts a number of mechanisms designed to restrict the ability of individuals to use charities for selfish or self-regarding purposes. We have, in a sense, created a tax-exempt regime that reflects both our desire for altruism in charities and the practical difficulties involved in ensuring actual altruism. From an individual's perspective, the nondistribution constraint and the private inurement restriction prohibit charities from distributing net earnings to individuals or enriching individuals through other means. From the entity's perspective, the restriction of activities to charitable purposes prevents organizations from engaging in non-charitable activities. If we were to stop here, we might have some sense of resigned contentment: we are not requiring absolute altruism, but perhaps we've done our best. But there are a number of exceptions that undermine these mechanisms and allow tax-exempt entities to engage in activities that work against any reasonable definition of altruism. Of most relevance to this Article, the Code permits charities to pay salaries and participate in the commercial market.

\section{Reasonable Salaries}

As mentioned in the Introduction, charities are permitted to compensate their employees. To many, the fact that the charities can pay salaries at all is surprising, let alone the fact that many executives of charities have quite handsome compensation packages. An intuitive and reasonable reading of the statutory private inurement prohibition ("no part of the net earnings ... inures to the benefit of any private shareholder or individual" $)^{60}$ suggests that a charity cannot provide any compensation. Indeed, it is hard to conceive of a salary as anything other than giving a portion of the "net earnings" of a charity to a "private ... individual." But as with most aspects of the law governing charities, the plain meaning of the Code is not controlling, and charities may pay salaries to employees to the extent that the salaries are reasonable. ${ }^{61}$

The permissibility of salaries suggests that policymakers are not interested in approximating altruism through the laws governing charities.

\footnotetext{
${ }^{60} 26$ CFR 1.501(c)(3).

${ }^{61}$ Hopkins, supra note [__ ] at 513 ( "A tax-exempt organization ... can, of course, make ordinary and necessary expenditures in furtherance of its operations without forfeiting its exempt status. This includes the payment of compensation for services rendered, whether to an employee or to a vendor, consultant, or other independent contractor.").
} 
Indeed, from the perspective of salaries, there is some evidence suggesting that altruism is neither intended nor desired. In terms of legislative history, lawmakers noted that those working for charities "need not necessarily accept reduced compensation merely because he or she renders services to a tax-exempt, as opposed to a taxable, organization." ${ }^{\text {, }}$ This legislative history serves as evidence against the altruism presumption: the lawmakers imply that charity salaries are no different from for-profit salaries. Indeed, this statement appears to be an absolute refutation against the assumption that we prefer our charities to be as altruistic as possible. This is echoed in case law, where courts have repeatedly refused to require any selflessness on the part of a charity's employees. As one court noted, the law "places no duty on individuals operating charitable organizations to donate their services; they are entitled to reasonable compensation for their efforts.",63

We should, however, be careful not to draw too many conclusions from these statements. In keeping with the relatively haphazard theoretical foundation of almost all charity law, the provision of reasonable salaries is founded on ill-defined policy justifications. As an exception to the private inurement prohibition, itself an "elusive, elastic, and evolving theory rather than a safely articulated standard,"64 the fact that charities may pay salaries enjoys virtually no theoretical justification. Further, although the legislative history and some courts suggest that salaries for charities' employees ought to receive no extra scrutiny, the fact remains that salaries paid by charities are not unrestricted. Salaries paid by charities must be reasonable, both in absolute amount (as compared to other organizations) ${ }^{65}$ and in relation to the assets of the organization. ${ }^{66}$ This is in sharp contrast to salaries paid by for-profit organizations, which are under no such limitations. ${ }^{67}$

${ }^{62}$ H. Rep. 104-506, $104^{\text {th }}$ Cong., 2d Sess. 56, note 3 (1976).

${ }^{63}$ World Family Corp. v. Comm'r, 81 T.C. 958, 969 (1983).

${ }^{64}$ See Jones, supra note [__ ] $[$ at 581.

${ }^{65}$ Hopkins, supra note [_ $]$ at 514.

${ }^{66} \mathrm{Id}$. at 514-15. (The test for reasonableness is not settled. Some courts apply a multifactor test, some apply an independent investor test, and some apply a combination of the two. "The factors commonly applied ... to ascertain the reasonableness of compensation are: The levels of compensation paid by similar organizations (tax-exempt and taxable) for functionally comparable positions, with emphasis on comparable entities in the same community or region; the need of the organization for the services of the individual whose compensation is being evaluated; the individual's background, education, training, experience, and responsibilities; whether the compensation resulted from arms' length bargaining ...; the size and complexity of the organization...; the individual's prior compensation arrangement; the individual's performance; the relationship of the individual's compensation to that paid to other employees of the same organization; whether there has been a sharp increase in the individual's compensation (a spike) from one year to the next; and the amount of time the individual devotes to the position.").

${ }^{67}$ Indeed, a for-profit company may pay as much as it likes to its employees. There is 
In the face of such mixed signals, it is difficult to suss out a coherent message. The private inurement restriction certainly suggests a preference for altruism by severely limiting the ability of individuals to personally benefit from the assets of a charity. However, this effort is undermined by the ability of charities to pay salaries. While the ability of charities to pay salaries suggests a regime that is not concerned with altruistic ideals, this conclusion is belied by the fact that those salaries are restricted. Regardless of the intent and the lack of coherence, the permissibility of salaries certainly diminishes any attempts to require or encourage altruism in charities.

\section{Commercial Activity}

To the extent it is surprising that charities pay salaries, it must be utterly shocking that charities may engage in commerce. An act of commerce, a quid pro quo exchange, may very well be the absolute antithesis of altruism. If a quintessential altruistic act is defined as "[w]hatever is given ... free from the stain or taint of every consideration that is personal, private, or selfish," 68 then a commercial transaction in which one party exchanges money for the services or goods of another certainly does not qualify as altruism. Indeed, if one is giving something in exchange for something else, one wonders if anything is "given" at all. But no matter how counterintuitive, it is becoming increasingly common for charities to engage in commercial activity.

It is important to note that the plain language of the Code does not appear to permit any commercial activity by charities. Section 501(c)(3) of the Code clearly states that tax-exemption is only permitted for organizations "organized and operated exclusively" for a defined charitable purpose. ${ }^{69}$ As Professor John Colombo notes, although it this appears that the Code "states in no uncertain terms" that a charity must restrict its activity to charitable purposes, therefore not permitting any commercial activity, "[t]his section ... has almost never been interpreted literally."70 The IRS has stretched the definition of what, precisely, constitutes activities that prove the charity is "operated exclusively" for charitable purposes, holding that "exclusively" means something akin to "mostly." So long as "not more than an insubstantial part" of the charity's activities is engaged in

no requirement that salaries be "reasonable." One need only look at the salaries of CEOs of publicly traded companies to learn that reasonableness is not in the discussion.

${ }^{68}$ See discussion infra notes [ $[$ ] $]$

${ }^{69} 26$ CFR 1.501(c)(3). (emphasis supplied)

${ }^{70}$ John D. Colombo, Commercial Activity and Charitable Tax Exemption, 44 WM. \& MARY L. REV 487, 496 (2002). 
something other than one of the enumerated charitable purposes, the charity is deemed to be operated "exclusively" for charitable purposes. ${ }^{71}$ The practical implications of this interpretation is that charities may engage in some commercial activities, and, for over nearly a century, courts and the IRS have crafted several tests to determine how much and what types of commercial activities are appropriate for charitable organizations. ${ }^{72}$ Further, a charity may engage in unlimited amounts of commercial activity if such activity is related to the charity's exempt purpose. ${ }^{73}$

The murky nature of the test that purports to identify what, precisely, constitutes commercial activity that is related to the charity's purpose, is not within the scope of this paper. However, it is important to know the policy considerations that undergird the limitation of commercial activities by charities. While there are a number of concerns, including the fact that commercial activities divert attention from charitable activities, ${ }^{74}$ a question of whether a charity's commercial activity creates market inefficiencies, ${ }^{75}$ and the fear that a charity's assets might be exposed to liabilities of the commercial activity, ${ }^{76}$ this Article will restrict the discussion to what Professor Colombo labeled the "traditional" policy concerns: the twin fears of unfair competition and the erosion of the corporate tax base.

To state the first traditional policy concern bluntly, there is a fear that tax-exempt organizations that engage in commercial activity might have an unfair competitive advantage over for-profit actors because charities do not

${ }^{71}$ See Hopkins, supra note [_ $[$ ] $]$.

72 For a complete discusson of the history of commercial activity by 501(c)(3) organizations, see Id.

${ }^{73}$ A charity may also engage in a certain amount of commercial activity that is unrelated to its charitable purpose so long as the charity pays taxes on any revenues generated through such activities. This taxable revenue is known as unrelated business income, and if a charity incurs too much, then the charity jeopardizes its 501(c)(3) status. However, the test for what, precisely, constitutes an amount of unrelated business income that would jeopardize an organization's tax-exempt status is not entirely clear. And like many of the restrictions on tax-exempt entities, the justification for the imposition of tax on unrelated business income is a bit muddled.

${ }^{74}$ See Colombo supra note [_ _ ] at 534. Professor Colombo calls this the "diversion problem," and explains that "[t]his argument views commercial activity by nonprofits as inherently bad because it diverts the attention of managers and resources away from the core charitable mission and core charitable outputs."

${ }^{75}$ See Id. at 538 “[T]hese issues revolve around whether an exempt charity's operation of a commercial activity creates inefficiencies in the capital markets or the distribution of goods and services that would not result from competition by for-profits only or if nonprofits concentrated their resources solely on production of charitable outputs."

${ }^{76} \mathrm{Id}$. at 544 "There certainly is a legitimate public interest in ensuring that charitable assets, the creation of which has been at least partially subsidized by tax-exemption, are not squandered in the operation of noncharitable businesses." 
have to pay taxes. ${ }^{77}$ The fear is that charities may use the fact that they are not subject to taxes to engage in predatory pricing. In other words, once a charity is relieved of the burden of paying taxes on a commercial activity, it may price its goods or services lower than for-profit entities, thereby engaging in unfair competition. In addition to predatory pricing, another example of potential unfair competition by charities is "subsidized market expansion," or "the possibility that an exempt organization will unfairly expand market share by using its tax savings to reinvest in its commercial activity, thus expanding the activity with a source of money (tax exemption) unavailable to nonexempt for-profit competitors." 78 Although many commentators have noted that there is no evidence that charities engage in either predatory pricing or subsidized market expansion, ${ }^{79}$ the fear of unfair competition remains one of the core reasons for the imposition of tax on the commercial activity of charities.

In addition to the fear of unfair competition, the other traditional policy concern regarding charities engaging in commerce is the effect on the tax base. As noted in the Introduction, the nonprofit sector makes up a significant portion of the American economy. Thus, there is a serious concern that our country is foregoing substantial revenues by bestowing tax-exemption on charities. For this reason, the commercial activities of charities that are unrelated to the entity's charitable purpose are subject to taxes. This is known as the unrelated business income tax. Removing potential income from the tax base was a "major concern" of Congress in imposing a tax on unrelated business income. ${ }^{80}$ Discussing the limits of charitable organizations engaging in commercial activity is a well-worn territory, ${ }^{81}$ not the least of which because of the impact it would have on the

\footnotetext{
${ }^{77}$ Id. at 530 "An example would be a sort of 'predatory pricing' in which an exempt organization prices its product below its competitors because it does not have to recoup the costs of taxation."

${ }^{78}$ Id. at 530 .

${ }^{79}$ Id. at 530 "In fact, legal academics and economists who have examined the issue have reached an almost remarkable consensus that unfair competition in the form of predatory pricing or predatory market expansion simply is not a serious policy concern." Citing, Boris Bittker \& George Rahdert, The Exemption of Nonprofit Organizations from Federal Income Taxation, 85 Yale L. J. 299 (1976), Henry Hansmann, Unfair Competition and the Unrelated Business Income Tax, 75 Va L. Rev. 605 (1989), William A. Klein, Income Taxation and Legal Entities, 20 UCLA L. Rev. 13 (1972), Susan Rose-Ackerman, Unfair Competition and Corporate Income Taxation, 34 Stan L. Rev. 1017 (1982), and Richard Steinberg, "Unfair" Competition by Nonprofits and Tax Policy, 44 Nat'1 Tax J. 351 (1991). Professor Colombo concludes that "even though unfair competition was the primary rationale for enacting the UBIT, it in fact may not be a very serious policy concern in practice."

${ }^{80}$ Id. at 532.

${ }^{81}$ See J. Bennett and G. Rudney, A Commerciality Test to Resolve the Commercial
} 
tax base. Indeed, "it is not overly cynical to suggest that some members of Congress would be willing to cede parts of the formerly exempt nonprofit sector to for-profit firms in return for the tribute of additional tax revenue." $" 82$

Both of the traditional concerns regarding commercial activity by charities-unfair competition and the shrinking tax base-suggest significant costs of charitable organizations engaging in for-profit activity. Although there is little evidence to suggest that charities engage in any unfair competitive activities, the potential for abuse certainly exists. And unfair competition aside, the shrinking tax base is of undeniable significance.

\section{An Eroding Altruism}

Thus, while several aspects of the tax-exempt regime appear to have roots in approximating altruism, with several mechanisms restricting individuals from taking advantage of charitable assets, these prohibitions are undermined by compromises that permit charities to pay salaries and engage in commercial activity. There are certainly good arguments to permit such activities. Perhaps charities must pay salaries to entice qualified individuals to leave the promised riches of the private market. And perhaps the commercial activities of charities serve to bolster the limited assets necessary to engage in good works. But the fact remains that neither salaries nor commercial activity are consistent with any reasonable conception of altruism. We therefore have a regime that bestows charitable status upon entities that engage in activities that most members of the public would deem relatively uncharitable.

The ability for entities to pay salaries and engage in commercial activities gives rise to the possibility of abuse. An immoral individual might take advantage of this situation by approving an undeserved salary or engaging in unfair competition. To ensure that charitable assets are not misappropriated in the form of unreasonable salaries, innocent actors in the private market are protected from unfair competition, and the nation's tax base is as robust as possible, it is in our best interest to ensure that taxexemption is awarded only to deserving entities and not those actors with

Nonprofit Issue, TAX NOTES, September 14, 1987, 1095-1098, arguing, in part, that organizations that receive more than $50 \%$ of their revenue from commercial activity should not be deemed tax-exempt. Interesting for purposes of this Article, Bennett and Rudney also argue that any commercial activity which is priced significantly below cost to targeted individuals should not be considered commercial. See also, Colombo and Hall, supra note

[__ ] , arguing that contributions should make up 1/3 of the gross revenue of charities.

${ }^{82}$ See Atkinson, supra note [_ _ ] at 507-08. 
ill-intent. Given the severity of the stakes, the next section's examination of the current process for determining tax-exempt status will prove to be wholly disappointing.

\section{How We Determine Charitable Status}

In the not-too-distant past, a common inquiry to the IRS's Exempt Organization division was, "Have you reviewed my tax-exempt application yet?" In fact, the question was so frequent that the IRS created a webpage that posted the average age of pending tax-exempt applications and an estimated wait time for applicants to expect a decision. For nonprofit professionals, attorneys representing charities, and anxious leaders of nonprofits awaiting their determination letter, a visit to the IRS's Where's My Exemption Application? website was a weekly occurrence.

The information provided by the Where's My Exemption Application website was minimal, but precious. Due to increasingly severe budget cuts, the IRS was simply unable to review tax-exempt applications in a timely manner. ${ }^{83}$ The Where's My Exemption Application website was the only way for would-be charities to get an idea of when they might learn the outcome of their tax-exempt application. For example, a visitor to the website in July 2014 would see the following notice: "The average age of our pending application inventory now is October 2013."84 This meant that applicants who had submitted an application approximately ten months prior were still waiting for the IRS to issue a determination on their taxexempt status. ${ }^{85}$ If ten months were not alarming enough, it is important to note that this is an average age, and there were certainly many applications that were submitted much earlier than October. ${ }^{86}$ But however meager or dispiriting, the Where's My Exemption Application website was the best way for aspiring charities to check on the status of their applications.

Today is much different. If you go to the IRS's Where's My Exemption Application website today, you get a very different message. Rather than a

${ }^{83}$ Yin, supra note [__ ] at 268. ("The reasons for this change are pretty clear. The IRS has accumulated a massive backlog of applications, causing unacceptable delays in their processing, and it is now under severe budgetary constraints, with no relief in sight.")

84 "IRS Announces Shorter, Faster Application For Some Tax Exempt Organizations", Forbes, July 1, 2014, available at www.forbes.com/sites/kellyphillipserb/2014/07/01/irsannounces-shorter-faster-application-for-some-tax-exempt-organizations/.

${ }^{85}$ Id. "Yes, that does mean that ten months-or about 300 days-after an initial application, organizations are still waiting to hear about tax-exempt status. That kind of wait time is ridiculous not only for tax exempt organizations but for individuals who wish to support them."

${ }^{86}$ As anecdotal evidence, one of my clients waited for over two years before receiving the IRS determination letter on a tax-exempt application. 
notice of the average age of the current application backlog, visitors are greeted with a cheerful assertion that the "inventory of applications is current." ${ }^{, 87}$ As if this boast was not enough, the IRS appears confident that it will not fall behind again. So confident, in fact, that the IRS no longer keeps track of the average age of pending applications and has effectively shut down the Where's My Exemption Application? website. ${ }^{88}$

What accounts for this newfound efficiency? Did the IRS suddenly hire more employees to review applications? ${ }^{89}$ Did it reallocate resources to address the backlog? Did it implement a more efficient review process?

The answer is that the IRS adopted a streamlined application process for smaller charities. To combat the application process's inefficiency and address the delays, the IRS determined that it was inappropriate to have all charities undergo the "same lengthy application process" regardless of whether the charity was "a small soccer or gardening club or a major research organization." $" 90$ Thus, the Form 1023-EZ was born in the summer of 2014.

In place of the familiar Form 1023, a relative behemoth of a document that boasted a 26-page length (before accounting for exhibits and attachments), the Form 1023-EZ is a three-page online application consisting primarily of attestations and questions that require little more than a simple "yes" or "no." The Form 1023-EZ supplemented a tax-exempt application process that has persisted for over half a century, ${ }^{91}$ providing a streamlined and user-friendly application for entities that met certain asset ${ }^{92}$

87 Where's My Exemption Application, available at www.irs.gov/Charities-\&-NonProfits/Charitable-Organizations/Where's-My-Application.

${ }^{88}$ The IRS has "retired the monthly date for the average age of pending applications." See Where's My Application, available at

${ }^{89}$ This is certainly not the case, as budget cuts have forced the IRS to lay-off a frighteningly high number of employees. "Between 2010, the year before Republicans took control of the House of Representatives, and 2014, the I.R.S. budget dropped by nearly $\$ 2$ billion in real terms, or nearly 15 percent. That has forced it to shed about 5,000 high-level enforcement positions out of about 23,000, according to the agency." Noam Scheiber and Patricia Cohen, For the Wealthiest, a Private Tax System That Saves Them Billions, NY Times, December 29, 2015.

${ }^{90}$ IRS Press Release, July 1, 2014, New 1023-EZ Form Makes Applying for 501(c)(3) Tax-Exempt Status Easier; Most Charities Qualify, available at https:/www.irs.gov/uac/Newsroom/New-1023-EZ-Form-Makes-Applying-for-501c3TaxExempt-Status-Easier-Most-Charities-Qualify (IRS Press Release).

${ }^{91}$ Viswanathan, Manoj (2014), Form 1023-EZ and the Streamlined Process for the Federal Income Tax Exemption: Is the IRS Slashing Red Tape or Opening Pandora's Box?, University of Pennsylvania Law Review Online: Vol. 163, Article 4 at 89, available at: http://scholarship.law.upenn.edu/penn_law_review_online/vol163/iss $1 / 4$ (citing James J. Fishman, Stealth Preemption: The IRS's Nonprofit Corporate Governance Initiative, 29 VA. TAX REV. 545, 558-59 (2010)).

${ }^{92}$ Entities with more than $\$ 250,000$ in total assets may not use the Form 1023-EZ. See 
and gross receipt ${ }^{93}$ requirements.

If the sole goal was to address inefficiencies in the tax-exempt application process, the Form 1023-EZ was a success. The backlog of taxexempt applications has been addressed and the Where's My Exemption Application website has been rendered superfluous. But despite this success, the Form 1023-EZ is not without its critics. Indeed, the response to the Form 1023-EZ has been loud and mostly negative. Professor George Yin, one of the first legal academics to address the streamlined application, warned that the Form 1023-EZ paved the way for "insincere applicants" to "obtain tax-deductible contributions for all manner of nonqualifying activities and expenses." A4though Professor Yin concedes that the IRS is facing a severe resource shortfall, he ultimately concludes that the decision to permit a streamlined application process represents a "misallocation and general misuse of scarce resources available to ensure compliance in the exempt organization area." 95

The critics of the Form 1023-EZ argue that the streamlined process fails to educate the applicants and does not provide enough information for the IRS to gauge the applicant's worthiness.

\section{A. The Form 1023 vs. The Form 1023-EZ}

\section{The Form 1023}

Prior to the Form 1023-EZ, almost all charitable organizations that hoped to obtain tax-exempt status were required to complete the Form 1023. There were a few exceptions to this requirement, including churches and very small entities (under $\$ 5,000$ in gross receipts), but the vast majority of charitable entities were required to complete the Form 1023. The Form 1023 was initially introduced in 1951, largely spurred on by the increased scrutiny of tax-exempt organizations under The Revenue Act of 1950.

Since its introduction, the Form 1023 has undergone several revisions. The first incarnation of the Form 1023 was four pages in length, and it requested information concerning the applicant's charitable purpose, activities of the organization, sources of revenue, and lobbying. It also required applicants to provide certain financial information and a copy of

Form 1023-EZ Worksheet.

${ }^{93}$ Entities that have had more than $\$ 50,000$ in gross receipts in any of the previous three years or expect more than $\$ 50,000$ in any the next three years may not use the Form 1023-EZ. See Form 1023-EZ Worksheet.

${ }^{94}$ Yin, supra note [__ ] at 269.

${ }^{95}$ Id. at 267. 
the organization's bylaws and formation documents. Since its first incarnation, the Form 1023 has evolved into a much more searching and fulsome document. ${ }^{96}$ The modern Form 1023's main section is twelve pages long, and the application includes 14 additional pages of schedules that are required for certain organizations. ${ }^{97}$ The instructions on how to complete the Form 1023 are 38 pages long, and the application requires a number of attachments. With all attachments, the completed Form 1023 proves to be a quite a lengthy document. In addition to requiring the organization to submit a copy of its formation documents ${ }^{98}$ and bylaws, ${ }^{99}$ the Form 1023 also requires submission of the names and biographies of the initial members of the board of directors, ${ }^{100}$ the salaries of the five highest paid employees, ${ }^{101}$ and several years' worth of pro forma financial statements. ${ }^{102}$ These requests, however, represent a relatively small percentage of most completed Form 1023s. The bulk of a completed application is generally in response to the prompt in Part IV of the Form 1023. This section requires a narrative description of the organization's activities, which "[d]escribe[s] completely and in detail [the organization's] past, present, and planned activities." 103

The Part IV narrative is where the applicant organization makes the case that it deserves tax-exempt status. The narrative is the opportunity for the applicant to "fully describe all of the activities in which it expects to engage, including standards, criteria, procedures, or other means adopted or

${ }^{96}$ Advisory Committee on Tax Exempt and Government Entities (ACT), page 6, June 6, 2012, available at http://martinlegalhelp.com/docs/EO_ACT_Report-Final-June2012.pdf

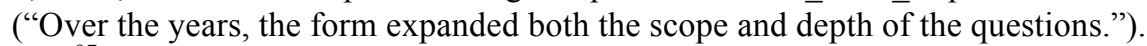

${ }^{97}$ The schedules apply to the following organizations:

\begin{tabular}{|l|l|}
\hline Schedule A & Churches \\
\hline Schedule B & Schools, Colleges, and Universities \\
\hline Schedule C & Hospitals and Medical Research Organizations \\
\hline Schedule D & Section 509(a) Supporting Organizations \\
\hline Schedule E & Organizations Not Filing Form 1023 Within 27 Months of Formation \\
\hline Schedule F & Homes for the Elderly or Handicapped and Low-Income Housing \\
\hline Schedule G & Successors to Other Organizations \\
\hline Schedule H & $\begin{array}{l}\text { Organizations Providing Scholarships, Fellowships, Educations } \\
\text { Loans, or Other Educational Grants to Individuals and Private } \\
\text { Foundations Requesting Advance Approval of Individual Grant } \\
\text { Procedures }\end{array}$ \\
\hline
\end{tabular}

\footnotetext{
${ }^{98}$ See Form 1023 Checklist, Form 1023

${ }^{99}$ See Form 1023, Part II.5.

${ }^{100}$ See Form 1023, Part V.3a.

${ }^{101}$ See Form 1023, Part V.b.

102 See Form 1023, Part IX.

${ }^{103}$ Form 1023 instructions, page 8 .
} 
planned for carrying out the [charitable] activities." ${ }^{104}$ Although the IRS ultimately approves most Form 1023 tax-exempt applications, it reserves the right to deny tax-exempt status if the application does not present a "meaningful explanation of [the organization's] activities," or if the application "provides only general information, lacks sufficient detail, does not fully describe the organization's programs, [or] is otherwise vague." ${ }^{105}$ The Part IV narrative is the best opportunity for applicants to convince the IRS that the organization's activities are appropriately charitable to justify tax-exempt status.

Once you combine the form itself, the required attachments, and the Part IV narrative, a properly completed Form 1023 is an impressive document. According to a private group that provides guidance on completing the Form 1023, "a typical application package is between 50-100 pages of material." 106

\section{The Form 1023-EZ: "A radical change to a decades-old process" 107}

It is difficult to imagine how the Form 1023-EZ could be more different from the Form 1023. In place of the Form 1023's rather impressive 26-page length, the Form 1023-EZ boasts no more than three pages. And as the following section explains, describing the form as "three pages" might overstate the substance of the actual form.

Part I of the Form 1023-EZ elicits mostly factual information about the organization. This includes the name and contact information of the organization, and the names and addresses of the officers and directors. Interestingly, there is room for only five entries in the officers and directors section, and the instructions tell applicants not to bother listing more than five individuals. ${ }^{108}$ Thus, it is likely that some members of the board of

${ }^{104}$ See Hopkins, supra note [__ ] at 798.

${ }^{105}$ Id. at 799 (internal quotation marks omitted).

${ }^{106} \mathrm{https}$ ://www.501c3.org/frequently-asked-questions/how-long-does-it-take-tocomplete-form-1023/

${ }^{107}$ Viswanathan, supra note [_ ] at 89.

${ }^{108}$ According to the instructions to the Form 1023-EZ, if an organization has "more than five [officers, directors, or trustees], list only five in the [following] order below.

1. President or chief executive officer or chief operating officer.

2. Treasurer or chief financial officer.

3. Chairperson of the governing body.

4. Any officers, directors, and trustees who are substantial contributors (not already listed above).

5. Any other officers, directors, and trustees who are related to a substantial contributor (not already listed above).

6. Voting members of the governing body (not already listed above).

7. Officers (not already listed above)." 
directors will not appear on an organization's tax-exempt application.

Part II of the Form 1023-EZ, consisting of seven questions, appears to have two functions: (i) information gathering similar to Part I and (ii) soliciting attestations. The information gathering section elicits the state of formation for the applicant and the organization's date of formation, while Part II requires a number of attestations that the applicant has appropriate provisions in its organizing documents, including a provision that limits the organization to charitable activities and a provision that ensures appropriate distribution of assets upon dissolution.

Part III of the Form 1023-EZ also gathers information, including the National Taxonomy of Exempt Entities Code and the category of charitable work for which the organization is organized. Part III also requires the applicant to answer eight "yes" or "no" questions regarding the entity's plans to influence legislation, pay salaries to insiders, pay funds to individuals, work with foreign organizations, engage in insider transactions, incur unrelated business income in excess of $\$ 1,000$, engage in gaming activities, or provide disaster relief. ${ }^{109}$

Part IV of the Form 1023-EZ is no more than the applicant's declaration of its intent to operate as either a public charity or a private foundation. Depending on the applicant's selection, the form requires an appropriate attestation. For example, if the organization claims to qualify as a public charity under Section 509(a)(1) and 170(b)(1)(A)(vi), it must attest that it either receives at least one-third of its support from contributions from the general public, or meets the 10 percent facts and circumstances test. ${ }^{110}$ Part $\mathrm{V}$ of the Form 1023-EZ is irrelevant for first-time applicants, ${ }^{111}$ and Part VI is a signature.

As this section and the immediately preceding section make clear, the differences between the Form 1023 and the Form 1023-EZ are substantial. The chart below illustrates the major differences between the Form 1023 and the Form 1023-EZ:

\begin{tabular}{|l|l|l|}
\hline \multicolumn{1}{|c|}{ Requirement } & \multicolumn{1}{c|}{ Form 1023 } & \multicolumn{1}{c|}{ Form 1023-EZ } \\
\hline $\begin{array}{l}\text { Organizational documents } \\
\text { must limit activities to } \\
\text { charitable purposes }\end{array}$ & $\begin{array}{l}\text { Requires copies of the } \\
\text { organizational documents (the } \\
\text { articles of incorporation and } \\
\text { bylaws) and an indication of the } \\
\text { location of such provisions. } \\
\text { Form 1023, Part III, line 1 }\end{array}$ & $\begin{array}{l}\text { Form 1023-EZ, Part II, } \\
\text { line 5 }\end{array}$ \\
\hline
\end{tabular}

${ }^{109}$ See Form 1023-EZ, Part III, lines 4-11.

${ }^{110}$ See Form 1023-EZ, Part IV, line 1a.

${ }^{111}$ See Form 1023-EZ, Part V, which instructs the applicant to complete the section only if the applicant is seeking reinstatement. 


\begin{tabular}{|c|c|c|}
\hline $\begin{array}{l}\text { Organizational document } \\
\text { must not permit } \\
\text { engagement in substantial } \\
\text { non-exempt activities }\end{array}$ & $\begin{array}{l}\text { Requires copy of organizational } \\
\text { documents and an indication of } \\
\text { the location of such provisions. } \\
\text { Form 1023, Part III, line 1 }\end{array}$ & $\begin{array}{l}\text { Requires attestation. } \\
\text { Form 1023-EZ, Part II, } \\
\text { line } 6\end{array}$ \\
\hline $\begin{array}{l}\text { Organizational document } \\
\text { must have appropriate } \\
\text { dissolution provision }\end{array}$ & $\begin{array}{l}\text { Requires copy of organizational } \\
\text { documents and an indication of } \\
\text { the location of such provisions. } \\
\text { Form 1023, Part III, line } 2\end{array}$ & $\begin{array}{l}\text { Requires attestation. } \\
\text { Form 1023-EZ, Part II, } \\
\text { line } 7\end{array}$ \\
\hline Compensation & $\begin{array}{l}\text { Requires list of five highest paid } \\
\text { officers, directors, trustees, } \\
\text { employees, and independent } \\
\text { contractors and the amount of } \\
\text { compensation for each. }{ }^{12} \text { Form } \\
1023 \text {, Part V }\end{array}$ & $\begin{array}{l}\text { Asks a yes or no question } \\
\text { regarding compensation } \\
\text { for officers, directors, and } \\
\text { trustees (not employees or } \\
\text { independent contractors). } \\
\text { Form 1023-EZ, Part III, } \\
\text { line } 5\end{array}$ \\
\hline $\begin{array}{l}\text { Description of } \\
\text { organizational activities }\end{array}$ & $\begin{array}{l}\text { Part IV narrative required. Form } \\
1023 \text {, Part IV }\end{array}$ & $\begin{array}{l}\text { No narrative required; } \\
\text { attestation as to charitable } \\
\text { activities. Form } 1023-E Z \text {, } \\
\text { Part II, lines } 5 \text { and } 6\end{array}$ \\
\hline Conflicts of interest & $\begin{array}{l}\text { Disclosure of related parties and } \\
\text { potential conflicts of interest } \\
\text { required. A conflicts of interest } \\
\text { policy, if in place, must be } \\
\text { submitted. If organization has } \\
\text { any contracts or arrangements } \\
\text { with an insider, it must be } \\
\text { disclosed. Form 1023, Part V }\end{array}$ & $\begin{array}{l}\text { Requires attestation. } \\
\text { Form 1023-EZ, Part III, } \\
\text { line } 8\end{array}$ \\
\hline $\begin{array}{l}\text { Close connection with } \\
\text { other organization }\end{array}$ & $\begin{array}{l}\text { If a close connection with } \\
\text { another organization exists, the } \\
\text { applicant must explain the } \\
\text { relationship. Form 1023, Part } \\
\text { VIII, line 15 }\end{array}$ & No disclosure required \\
\hline Financial Data & $\begin{array}{l}\text { Requires disclosure of basic } \\
\text { financial information for each } \\
\text { year in existence and as many as } \\
\text { four years of estimated finances. } \\
\text { Form } 1023, \text { Part IX }\end{array}$ & No disclosure required \\
\hline
\end{tabular}

The ultimate result is a significantly lighter burden on the applicant organization. According to IRS estimates, applicants should expect to spend about 19 hours to complete the Form 1023-EZ. ${ }^{13}$ While 19 hours may

${ }^{112}$ Please note that the applicant does not need to list this information for employees and independent contractors if the salary is less than $\$ 50,000$ per year.

${ }^{113}$ See Form 1023-EZ Instructions, page 10. This includes 10 hours and 2 minutes of recordkeeping, 2 hours and 30 minutes of learning about the law or the form, five hours and thirty-three minutes to prepare the form, and 48 minutes for copying, assembling, and sending the form to the IRS. Please note, however, that critics contend that it may not even take this long. Delaney: "I could easily see many applicants spending as little as an hour or 
appear to be an attractively short amount of time, the estimate is even more impressive when one considers that the IRS estimates that applicants will spend 105 hours completing the Form 1023. ${ }^{114}$ Needless to say, an estimated difference of over two full 40 -hour weeks is significant. Indeed, it is difficult to conceive of a more dramatic difference in tax-exempt applications. The Form 1023-EZ eschews many requirements that long-time nonprofit professionals may find jarring. Most notably, the Form 1023-EZ does not require a narrative description defending the charitable nature of the organization's activities, any financial data, or any actual copies of the organizational documents. According to Professor Manoj Viswanathan, such changes represent nothing less than a "radical change to a decades-old process." $" 115$

\section{B. Why The Streamlined Process Fails}

The arguments against the Form 1023-EZ were swift and multifaceted. While commentators managed to attack virtually every aspect of the new application, the criticisms may accurately be categorized as charges that the Form 1023-EZ lacks either (i) the educational component of the Form 1023 that prepared applicants for proper operation as a charitable organization or (ii) the substantive rigor to permit the IRS to properly assess applicants, thereby betraying the public's trust. This section will describe the crux of each of these arguments.

\section{The Form 1023-EZ Fails the Educational Role}

The first category of criticisms highlights the fact that the traditional Form 1023 plays a significant role in educating applicants on the proper activities and conduct of charitable organizations. By requiring the applicants to engage in, for example, the laborious process of completing the Part IV narrative, the organization is forced to consider each of the organization's past, present, and planned activities in a careful and critical manner. Not only does the Form 1023 request a description of the activities, but it also asks the organization to explain how the activity furthers the organization's exempt purpose. ${ }^{116}$ In theory, this requires a critical evaluation of each of the applicant's activities to determine the specific

so - not because they deliberately intend to skirt the law, but because they simply don't know or understand what they are required to certify." Delaney letter p. 3

114 This omits "the time needed to submit any required schedules." See Viswanathan, footnote 2

${ }^{115}$ Viswanathan, supra note [__ $]$ at 89.

${ }^{116}$ Form 1023 Instructions, $\mathrm{p} 8$. 
activity's charitable aims. As one critic of the Form 1023-EZ noted

[h]aving gone through the [Form 1023] application process with a museum I helped start, we were put through the ringer by the IRS which to some extent forced us to think through our plans (mission, vision, intent, how we would operate, etc.) ultimately, I believe, making us stronger. ${ }^{117}$

In addition to the Part IV narrative, the organization is also asked to provide financial information and projected financial information, requiring a thoughtful applicant to consider how much projects will cost and how the organization will raise such funds. ${ }^{118}$

Professor Bruce Hopkins suggests the rigor involved in completing the Form 1023 is by design. The Form 1023 prompts were drafted to inspire thoughtful responses by the applicant organization. As Professor Hopkins notes,

[t]he proper preparation of [a Form 1023] involves far more than merely responding to the questions on a government form. It is a process not unlike the preparation of a prospectus for a business in conformity with securities law requirements. Every statement made in the application should be carefully considered.... Organizations that are entitled to tax-exempt status have been denied recognition of exemption by the IRS, or at least have cause the process of gaining the recognition to be more protracted, because of unartful phraseologies in the application that motivated the agency to muster a case that the organization did not qualify for exemption. $^{119}$

To highlight this concern, the National Council of Nonprofits, in a letter criticizing the Form 1023-EZ, stresses that the streamlined process will rob future applicants of the educational component of the full Form 1023. ${ }^{120}$

As the previous section made clear, the Form 1023-EZ contains no requirements akin to either the part IV narrative or the required financial projections of the Form 1023. Indeed, the apparent simplicity of the Form

${ }^{117}$ Delaney letter, $\mathrm{p} 3$.

${ }^{118}$ Form 1023 instructions, Part IX.

${ }^{119}$ Hopkins, supra note [ $]$ at 802.

120 Council Letter page 9. The concerns set forth in the National Council for Nonprofit's letter were addressed point by point by Professor Manaj Vaswanathan. See Viswanathan, supra note [__ ] $]$ at 96-99. 
1023-EZ suggests that such searching self-assessment might not be necessary. Describing a hypothetical group of applicants as "sincere but not well advised," Professor Yin imagines such applicants as they

pore over the few sentences in the instructions summarizing the private inurement and benefit doctrines and other familiar parts of the law. How are they, working on their own, going to complete their required attestations? ${ }^{121}$

Professor Yin's concern is that the Form 1023-EZ does not provide the applicant with enough educational material to make an informed attestation. In fact, Professor Yin seems to suggest that one of the benefits of the complexity of the Form 1023 is that its difficulty had a positive outcome: it encouraged applicants to seek legal advice. The National Council for Nonprofit's letter echoes this sentiment, noting that although the process under the Form 1023 is cumbersome, "it requires effort and energy and pushed away those that are not prepared.... The [Form 1023] is overwhelming and is discouraging to some, but also a deterrent to those with only half-baked plans and ideas." $" 122$

2. The Form 1023-EZ Does Not Provide the IRS With Enough Information to Adequately Assess Applicants

In addition to the concern of the Form 1023-EZ's lack of an educational component, many critics have expressed concerns that the streamlined application does not elicit enough information. This relative lack of information gathering in the Form 1023-EZ has been derisively referred to as tax-exempt application equivalent of "don't ask, don't tell." ${ }^{23}$ Critics are concerned that this lack of information gathering paves the way for the IRS to award tax-exempt status to entities that should not qualify. Or worse, the lack of information gathering may provide the means for fraud.

The critics' fears may be well-founded. At least one study supports the notion that the Form 1023-EZ may result in the IRS awarding tax-exempt status to unfit entities. Nina Olson, the National Taxpayer Advocate, ${ }^{124}$ engaged a study with the IRS that implemented additional requirements for

${ }^{121}$ Yin, supra note [__ ] at 268.

122 Council letter, p. 2-3.

123 NY Times, Patricia Cohen, I.R.S. Shortcut to Tax-Exempt Status is Under Fire, available at http://www.nytimes.com/2015/04/09/business/irs-shortcut-to-tax-exemptstatus-is-under-fire.html. April 8, 2015.

${ }^{124}$ The National Taxpayer Advocate is an independent organization within the IRS that serves as an advocate for taxpayers who are experiencing delays or are suffering economic harm. 
411 organizations that submitted a Form 1023-EZ. ${ }^{125}$ Of these organizations, the IRS requested additional information, including "the organizing document of past, present, and future activities; revenues and expenses; and a detailed description of any transactions with donors or related entities." 126 In other words, these organizations were asked to provide much of the information they would have been required to submit under the traditional Form 1023. After review of this additional information, only $73 \%$ of the 411 applications were ultimately granted 501(c)(3) status. This is in contrast to the 95\% of all Form 1023-EZ applicants that ultimately receive 501(c)(3) status. ${ }^{127}$ As Jill MacNabb, an advisor to the National Taxpayer Advocate, noted, "there's a significant difference in the approval rate of a [Form] 1023-EZ just as it is and the approval rate when you ask for some very basic information."128 To many, these results are disturbing, as it strongly suggests that the IRS is providing tax-exempt status to entities that would not have qualified had they been required to submit the Form 1023. Or in the words of the National Taxpayer Advocate, the IRS granted 501(c)(3) status to "applications it would have rejected had the applications been subject to the slightest scrutiny."129

Another study by the Taxpayer Advocate Service provides more reason for concern. The Taxpayer Advocate Service set out to review the organizational documents of some entities that received 501(c)(3) status through the Form 1023-EZ to determine if the documents complied with IRS's organizational test, which requires a charitable organization to (i) limit its purpose to one or more exempt purpose, (ii) not expressly empower the organization to engage (other than insubstantially) activities which are not in furtherance of such purpose(s), and (iii) ensure that assets are properly distributed upon dissolution. ${ }^{130}$ Under the Form 1023-EZ, applicants simply attest that the organizational documents contain such a restriction. Under the Form 1023, the applicants must not only provide copies of the organizational documents, but also indicate precisely where

\footnotetext{
125 See "The IRS Approves Many Applications for Tax-Exempt Status Almost Automatically, Often Based on Insufficient Information" available at http://www.taxpayeradvocate.irs.gov/Media/Default/Documents/2016-

JRC/Area_of_Focus_8_Insufficient_Information_for_Tax_Exempt_Status.pdf

${ }^{126}$ See Id. at 73.

${ }^{127} \mathrm{Id}$.

${ }^{128}$ Tax Notes, October 5, 2015 "Taxpayer Advocate Official Concerned About EO Short Form."

${ }^{129}$ Id. at 74.

${ }^{130}$ See https://www.irs.gov/Charities-\&-Non-Profits/CharitableOrganizations/Organizational-Test-Internal-Revenue-Code-Section-501(c)(3). Note that organizations in some states can meet the dissolution requirement without a specific provision. The review took this factor into account.
} 
the provisions appear in such documents. ${ }^{131}$ Of the 13 entities reviewed, ${ }^{132}$ only three organizations met the organizational test. ${ }^{133}$ While a pool of 13 applications certainly does not provide a representative sample, the fact that less than a quarter of the organizations had the required provisions is troubling.

To say that the Form 1023-EZ does not provide the information that the IRS needs to assess applicants should be alarming enough. However, some critics suggest that the IRS is engaging in virtually no assessment. Citing a "high-ranking official," Professor Yin proffers that, with the Form 1023EZ, "the IRS has effectively created a self-certification process to obtain (c)(3) status. ${ }^{134}$ Professor Yin continues to state that the IRS has nothing to "screen and analyze" because the Form 1023-EZ is "a series of completely opaque attestations." 135

The concern that the IRS is awarding tax-exempt status to unworthy applicants is certainly alarming. However, it is somewhat mitigated by the fact that these mistakes are, presumably, unintentional. One might reasonably assume that an organization would not intentionally leave out a required provision in its charter documents in order to either engage in noncharitable activity or dissolve and distribute assets in contravention of 501(c)(3) requirements. However, critics maintain that the Form 1023-EZ may open the door to more insidious actors. Such critics are concerned that the lack of rigor in the Form 1023-EZ will make "it easier for 'scam' charities to obtain tax-exempt status," and the streamlines application shifts "IRS oversight obligations onto the public, the funding community, and state charity regulators." 136 Although sympathetic to the notion that the "long-established Form 1023 and application process need review and streamlining," 137 the National Council of Nonprofits ${ }^{138}$ also expressed "serious concerns" about the form, warning that potential "bad actors will ... opt to use the EZ express-lane approval process to avoid the transparency mandate that is integral to the current Form 1023 application

${ }^{131}$ See Form 1023, part III.

${ }^{132}$ The small number of applicants reviewed is because the inquiry was limited to those states that provide organizational documents free of charge.

133 The National Taxpayer Advocate interprets that this proves "there were organizations that have been approved that if we had just simply asked four questions we would not have approved them," Tax Notes, April 27, 2015, "Olson: Exemption Applicants Are Being Wrongly Approved."

${ }^{134}$ Yin, supra note [_] at 267-68, citing Fred Stokeld et al, "IRS Hearing on EO guidance Expected in Spring," Tax Notes, March 10, 2014, p. 1078.

${ }^{135}$ Id. at 269

${ }^{136}$ GAO Report, supra note [ $[$ ] at 32.

${ }^{137}$ Council Letter, supra note [_] $]$ at 1.

${ }^{138}$ Viswanathan, supra note [ [] at 95 (The National Council of Nonprofits represents the "largest network of nonprofits in the country"). 
process."139

Although the Form 1023-EZ requires applicants to attest that they meet the organizational test, this study indicates that applicants are incorrectly claiming compliance. If the false attestations were intentional, then the Form 1023-EZ's lack of rigor may be inviting fraud. If the false attestations were unintentional, then the Form 1023-EZ is failing to properly educate applicants. In either case, if the study's numbers are at all representative, ${ }^{140}$ the criticism that the IRS is not assessing applicants appears to carry weight. $^{141}$

The real difference is the approach. The Form 1023-EZ asks for attestations for certain requirements, whereas the Form 1023 requires proof. For critics, this difference is vital, and the Form 1023-EZ's shortcomings in eliciting certain information creates opportunity for fraud.

\section{An Opportunity to Make Charities More Altruistic}

After over a year of experience, the IRS is very pleased with the Form 1023-EZ. In a report issued a year after the streamlined form's introduction, the IRS boasts that the Form 1023-EZ "is reducing taxpayer burden and increasing cost effectiveness of [IRS] operations." ${ }^{\text {"142 }}$ While there may be some question as to the reduction of taxpayer burden, there is no doubt that the IRS is more efficient. The embarrassing backlog of tax-exempt applications has been eliminated; but at what cost?

Despite the chipper tone, the IRS is not deaf to the Form 1023-EZ critics. But rather than jettison the form altogether, as many critics might urge, the IRS has promised to adopt modest changes to the form. The specific details of the changes have not been released at the time of this Article, but in addition to some minor changes to the instructions, the

planned changes for the form include requiring the identification of a point of contact or responsible person for additional information requests, requiring the applicant to

\footnotetext{
${ }^{139}$ Council Letter, supra note [ _ ] at 7. "Likewise, the Taxpayer Advocate also raised concerns about the streamlined 1023-EZ form, including a lack of empirical data demonstrating that organizations anticipating less than $\$ 50,000$ in gross annual receipts pose low risks to compliance, a failure to conduct a comprehensive evaluation of downstream consequences of the streamlined application, and a post-implementation to correct potential compliance problems." GAO Report, supra note [_] ] at 32.

${ }^{140}$ With only 13 applications reviewed, this is certainly not a given.

141 Tax Notes, October 5, 2015, "Critics say Form 1023-EZ could allow unqualified organizations to obtain exemptions because it does not ask applicants for enough information about their activities."

${ }^{142}$ Form 1023-EZ First Year Report, Executive Summary available at [
} 
attest that gross receipts or expected gross receipts are less than $\$ 50,000$, and requiring an independent attestation that total assets are less than $\$ 250,000 .^{143}$

To say the least, the proposed changes to the Form 1023-EZ are slight. The IRS plans to add a contact person and include additional positive attestations regarding the qualifications of the organization. These changes are not likely to quell the concerns of critics, who believe that the Form 1023-EZ is both a dereliction of the IRS's gatekeeping duty, and an invitation to those who would use a tax-exempt organization to commit fraud.

The substance of the IRS's proposed changes makes it abundantly evident that the IRS does not share the dire concerns of the Form 1023-EZ's harshest critics. The changes do not address the potential misuse of the form, as the additional attestations are no barrier for an immoral individual who wants to use the streamlined application process to obtain 501(c)(3) status for personal enrichment. Although there is little evidence to show that such immoral actors are utilizing the Form 1023-EZ, it does not take a criminal mastermind to imagine the potential for exploitation.

Somewhat surprisingly, and certainly unintentionally, the IRS's solution to the administrative burden provides an opportunity to address the problem of charities that act in a less-than-altruistic manner. Rather than follow the advice of the harshest critics, we should embrace the Form 1023-EZ process as a chance to encourage more altruistic charities. In the IRS's desperate attempt to curtail its administrative burden, it has inadvertently presented the occasion to create a new family of charities - a group of charities that does not strain any traditional definition of "charity." As this section will argue, in exchange for the use of this streamlined process, these charities will agree to forgo salaried employees and commercial activity (together, paying salaries and engaging in commercial activity are referred to as "Disfavored Activities"). Such charities will, in a very real sense, be forced to operate in a more altruistic manner.

\section{A. Should We Treat Form 1023-EZ Filers Differently?}

One might be concerned that the prohibition of Form 1023-EZ filers from engaging in Disfavored Activities is a bit arbitrary. Does it logically follow that we should not allow entities to pay salaries or engage in commercial activity simply because we do not require as much information on the front end? Perhaps not, but there are two distinct reasons for

${ }^{143}$ Id. 
imposing such a restriction. The first is a response to the critics of the Form 1023-EZ: because the streamlined form creates a greater risk of immoral actors taking advantage of a charity for improper personal gain, we should do what we can to eliminate the potential for abuse (i.e., prohibit Disfavored Activities). And because such entities have reduced reporting requirements, there is no obvious means of monitoring the activities of Form 1023-EZ filers. Thus, it is reasonable to completely disallow Disfavored Activities. Second, and perhaps more importantly, banning Disfavored Activities would create a family of charities that is restricted from engaging in selfregarding activities, thereby creating a more altruistic charity.

\section{No Meaningful Oversight}

The financial threshold for entities allowed to use the streamlined application form, expected gross receipts below $\$ 50,000$, was chosen by the IRS to have the greatest impact. Designed to be as inclusive as possible, the IRS expected "most small organizations, including as many as 70 percent of all applicants, [will] qualify to use the new streamlined form." 144

At first blush, this might seem counterintuitive. Why, after all, would the IRS voluntarily opt to collect less information from the majority of applicants? A cynic might suggest that the IRS is merely trying to lessen its administrative burden, and a more inclusive threshold will make the review process easier. However, there is a less cynical justification: the IRS has already determined that organizations with less than $\$ 50,000$ in gross receipts are too small to warrant scrutiny. This decision is evident in the IRS's decision to require virtually no reporting from such entities.

Due to their tax-exempt nature, charities are not required to submit the tax returns required of for-profit entities. To bridge this gap, the IRS requires annual information returns. Through these returns, the IRS reviews and conducts oversight of charities not only at the inception of the entity's tax-exempt lifecycle (i.e., the Form 1023 or the Form 1023-EZ), but also on an annual basis thereafter. Such information returns are either the Form 990, Form 990-EZ, or Form 990-N. ${ }^{145}$

The information required by an annual information return varies depending on the size of the charity. Generally speaking, the more gross receipts realized by a charity, the more disclosure and information will be required. For entities that have annual gross receipts over $\$ 200,000$ or assets greater than or equal to $\$ 500,000$, the entity must submit a Form 990 . This

144 "It is expected that approximately seventy percent of the 80,000 organizations annually applying for tax-exempt status will be eligible to use Form 1023-EZ." - See Viswanathan, supra note [__ _ ] page 89-90.

${ }^{145}$ Private foundations must use another form, the 990-PF. 
annual information return, the most robust of the forms, requires the most detailed information. The Form 990 requires basic financial information, such as gross income, expenses, disbursements, a balance sheet, total contributions received (including the names and address of certain contributors), and salaries received by certain employees. Such information, required by Section 6033 of the Code, is the only means for the IRS to monitor the financial activities of the organization. In addition to financial information, a charity filing a Form 990 is required to provide narrative descriptions of the "three largest program services." descriptions must not merely describe the activities, but provide

specific measurements such as clients served, days of care provided, number of sessions or events held, or publications issued, [d]escribe the activity's objective, for both this time period and the longer-term goal, if the output is intangible, such as in a research activity, [and g]ive reasonable estimates for any statistical information. ${ }^{147}$

The Form 990 thus provides a tremendous amount of information, requiring charities to not only produce financial information, but also narrative descriptions of the charity's activities for the past year. Perhaps most importantly, in addition to submitting the Form 990 to the IRS, charities are required to make their Form 990s publicly available for inspection and copying. Thus, the IRS and the public have the opportunity to scrutinize the activities of charities, "providing ... a realistic picture of the [charity] and its operations, and promoting compliance with the federal tax law."148

The Form 990 is a detailed and robust information-gathering tool. It takes over 29 hours to learn about the law and almost 34 hours to complete the form. ${ }^{149}$ Recognizing this burden, the IRS does not require all entities to complete the Form 990. Charities that have annual gross receipts between $\$ 50,000$ and $\$ 200,000$ and assets under $\$ 500,000$ are required to complete a less rigorous annual information return, the Form 990-EZ.

The Form 990-EZ is a significantly streamlined form, but it still requires the basic financial information and narrative descriptions required by the Form 990. But in the interest of saving time for smaller organizations, the Form 990-EZ does not require command the Form 990's level of detail. The IRS estimates that it should take about 11.5 hours to learn about the law and

\footnotetext{
${ }^{146}$ As measured by expenses - Form 990, Part III, line 4.

${ }^{147}$ Form 990 instructions, page 11.

${ }^{148}$ Hopkins, supra note [ $[$ ] at 810 .

${ }^{149}$ Per the Paperwork Reduction Act: https://www.irs.gov/instructions/i990/ar02.html
} 
14.5 hours to prepare the form. ${ }^{150}$ This is less than half the time it takes for charities filing the Form 990.

The annual information returns for large and mid-sized charities (the Form 990 and Form 990-EZ, respectively), each require charities to provide some financial information and a narrative description of the charity's activities for the previous year. These charities must file these reports annually and make the information available to the general public. This provides some level of transparency for the public, and provides the information to the IRS for potential enforcement or investigatory purposes. For very small charities, however, the annual reporting requirement is quite different.

The IRS requires charities that have annual gross receipts of less than $\$ 50,000$ to file the Form $990-\mathrm{N}$, or e-Postcard. ${ }^{151}$ The information elicited by the e-Postcard is, to say the least, minimal. The form requires no financial information beyond an attestation that the charity's gross receipts are normally $\$ 50,000$ or less, and there is no requirement for a narrative description of the activities of the charity. In fact, other than the aforementioned attestation, there is no information other than the charity's name, address, website, and employer identification number, along with the name and address of a principal officer. Below is an example of a completed Form 990-N:

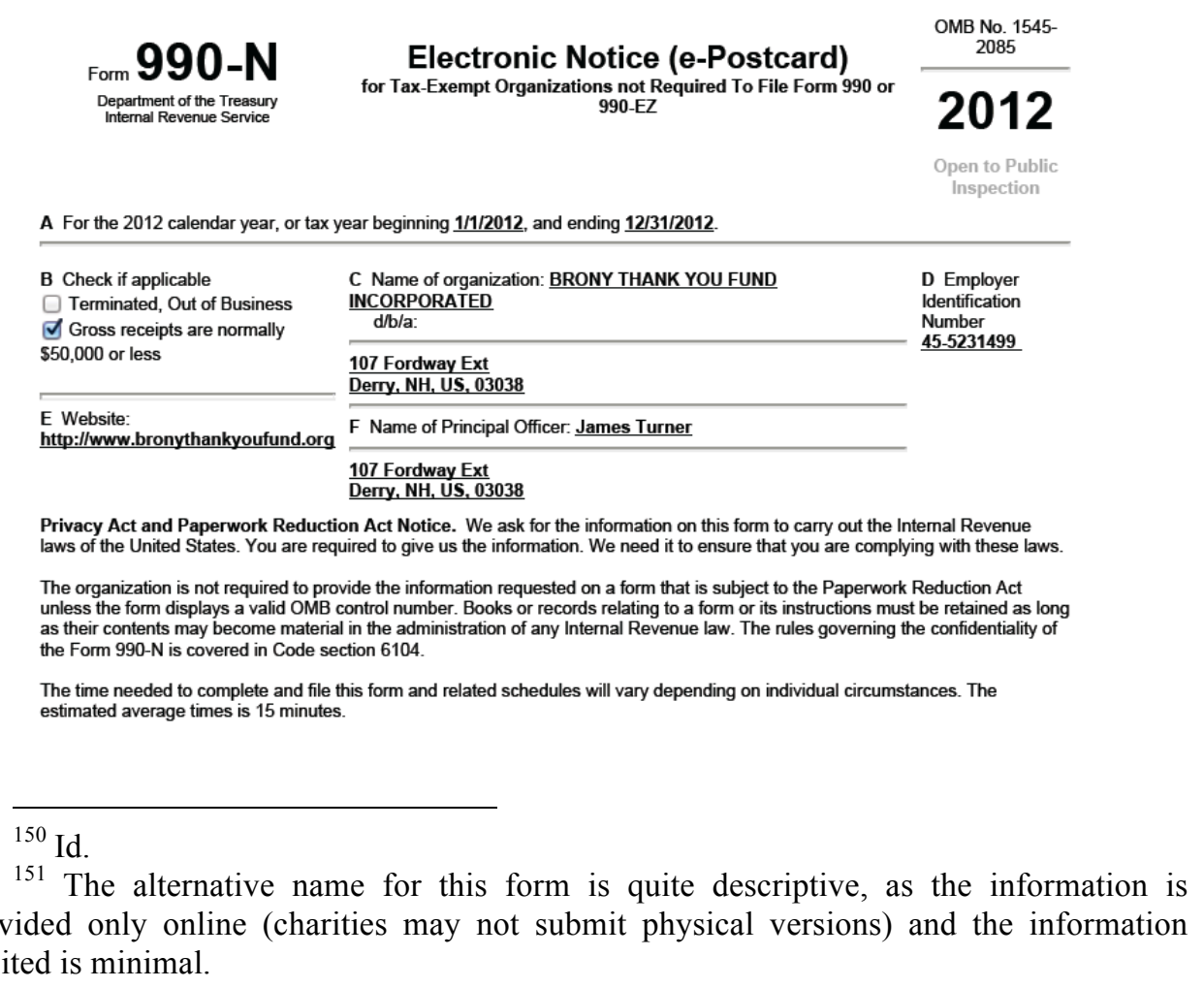
elicited is minimal. 


\section{Insufficiency of Disclosure for Small Charities}

The stated purpose of the annual information returns is to provide information about a particular organization. ${ }^{152}$ With this purpose in mind, the lack of required disclosure by the Form $990 \mathrm{~N}$ is alarming. As noted at the bottom of the Form 990-N, filers should expect to spend about 15 minutes to complete and file the form. There is virtually no financial information and absolutely no description of the charity's activities. Most notably for the purposes of this Article, there is no discussion of salaries paid and no disclosure of commercial activities. At no point is the organization required to provide any detailed financial information, and there is no opportunity for the IRS to gauge the Disfavored Activities. The organization may pay salaries without disclosing the amount of the salaries (and therefore providing no data with which to measure reasonableness) and the organization may engage in commercial activities that are related to the charity's purpose without any meaningful disclosure. ${ }^{153}$

Thus, if an organization has less than $\$ 50,000$ in gross receipts, there is virtually no transparency. At the outset of the organization's tax-exempt existence, the IRS requests the scant information required by the Form 1023-EZ. The Form 1023-EZ requires no financial information, no disclosures regarding salaries, ${ }^{154}$ and no discussion of commercial activities. Thereafter, the IRS annually requests the scant information required by the Form $990 \mathrm{~N}$.

\section{B. The Results: A More Charitable Charity}

On a recent Tuesday evening, in a public housing development about two miles north of the Las Vegas strip, a passerby would be forgiven for suffering from some cognitive dissonance. Amidst the rows of identical homes, poor lighting, and the ineffable dreariness of most public housing complexes built in the $60 \mathrm{~s}$, one hears a raucously spirited chorus of the Hokey Pokey. The singers are children, ranging in age from five to fourteen, who live in the Sherman Gardens public housing development. The children are at an afterschool program run by a small charity called the Nevada Youth Network, and they are coming to the end of the evening session. Twice a week, the Nevada Youth Network holds these sessions for children in the neighborhood. Shortly after the song's rousing ultimate refrain (you

152 See Form 990 instructions.

${ }^{153}$ Note that unrelated commercial activity over $\$ 1,000$ must be disclosed on a Form 990T for all organizations.

154 There is a "yes" or "no" disclosure regarding intent to pay salaries, but there is no narrative description or disclosure as to the amount. 
put your whole self in, you put your whole self out...), about two-dozen children quickly calm down, sit cross-legged in precise rows, and await instruction from Mike Flores. Mr. Flores, a volunteer and executive director of Nevada Youth Network, tells the children that it is time for yoga and asks for a volunteer to lead the group. An impossibly thin eight year old named TJ volunteers. It's no surprise that TJ volunteered, as he was one of the most enthusiastic singers in a particularly energetic and enthusiastic rendition of Hokey Pokey. Defying the residual energy of the song's performance, TJ sits calmly in front of the children and leads them in some breathing and light stretching exercises.

Prior to singing and yoga, the children spent an hour working on their homework, reading on their own, and listening to a volunteer read a book. After yoga, they will head home with a snack and a drink. This scene, with some variation, happens every Tuesday and Thursday in a pair of renovated units in the Sherman Gardens public housing development thanks to the Nevada Youth Network.

The Nevada Youth Network's mission is "foster[ing] the growth and independence of young people within communities of color." "155 The primary activity of the Nevada Youth Network has been the afterschool program. This program has been in operation for several years in the Sherman Gardens public housing development. The afterschool program is entirely volunteer-driven and has never been asked to pay rent.

After about two years of operation, the Las Vegas public housing authority asked for Nevada Youth Network's "tax-exempt paperwork," under the assumption that the Nevada Youth Network was a 501(c)(3) organization. This assumption was not terribly out of line, the organization certainly looked and acted like a tax-exempt organization: it did not charge for the services and it provided a free service to a needy population. The only problem was that this assumption was false. The leaders of the Nevada Youth Network never applied for tax-exempt status. They weren't trying to commit fraud or skirt their responsibilities, but they just didn't think 501(c)(3) status was necessary. After all, they were not planning to apply for any grants that required 501(c)(3) status, and they did not ask the general public for donations with the promise of tax-deductions. They were a nonprofit organization, but they did not see any need to apply for taxexempt status. Unfortunately, the public housing authority told the Nevada Youth Network that use of the space in Sherman Gardens would no longer be rent-free without proof of 501(c)(3) status.

Setting aside the wisdom of the public housing authority using the 501(c)(3) status as a proxy for whether or not the organization should be

\footnotetext{
${ }^{155}$ NYN website
} 
allowed to operate without paying rent, the Nevada Youth Network is an example of a charity tailor-made for the Form 1023-EZ.

The Nevada Youth Network's budget is virtually zero. The space is donated, the snacks are donated, and the volunteers donate their time. The organization does not engage in any commercial activities to raise funds. No salaries are paid. The organization simply opens its doors to children in need of a safe place after the school day ends. While the volunteers are richly rewarded on an emotional level, there is no expectation of pecuniary remuneration. It is, in a very real sense, an altruistic endeavor. Indeed, outside of the personal satisfaction provided by brightening a child's day, the entire endeavor is "free from the stain or taint of every consideration that is personal, private, or selfish." To the extent that we want to promote altruistic activity, this is the type of charity that should be encouraged. More to the point, it is the type of charity that would be encouraged by a Form 1023-EZ that did not permit Disfavored Activities.

\section{CONCLUSION}

Many areas of the law fail to meet the expectations of the laity, and charity law is no exception. Any colloquial conception of charity contains some expectation of altruism. While the plain meaning of many of the laws governing charities contain hints that such an expectation exists, over a century of case law and agency actions have removed any hint of requiring altruism. Compounding the problem, the IRS, the agency charged with the primary responsibility of overseeing charities is overburdened and underfunded. We are therefore left with a largely unsupervised regime that has largely abandoned altruistic ideals.

This does not have to be the case. Although the IRS's decision to create a virtual self-certification process for aspiring tax-exempt entities drew sharp criticism, it has also provided an opportunity to reconsider how we treat small charities. The criticisms of the streamlined application process can be reduced to the concern that immoral actors will use charities to commit fraud. Although there is talk of the Form 1023-EZ's failure to educate, ${ }^{156}$ the more urgent concern appears to be that dishonest individuals would use charities for personal enrichment. The logical response would be to impose strict policing mechanisms to ensure propriety. But given the defunding of the IRS and the lack of interest by state authorities, this is not realistic. Thus, in order to protect against fraud, the potential for fraud must be reduced, and the most direct means of reducing the potential for fraud is to remove the ability of charities to engage in activities that permit personal

\footnotetext{
${ }^{156}$ See infra notes [_ $]$.
} 
enrichment. In other words, we should ban the ability of entities that utilize the streamlined application process from engaging in Disfavored Activities. Although this will not render all charities more altruistic, it will help encourage a large portion of charities to act in a more altruistic manner, bringing the legal definition of charity closer to the popular conception of charity. 